\title{
Arbitragem Comercial Internacional e o Projeto da UNCITRAL (Lei-modelo)
}

\author{
Guido Fernando Silva Soares \\ Professor Adjunto do Departamento de Direito Internacional da \\ Faculdade de Direito da Universidade de São Paulo
}

\begin{abstract}
RESUMO: 1. O Direito do Comércio Internacional e a UNCITRAL. 2. A Arbitragem Comercial Internacional e Suas Fontes Normativas. 3. O Regulamento da UNCITRAL de 1976 e a Lei-Modelo de 1985. Conclusões. Bibliografia. ANEXOS: I - O Regulamento de Arbitragem da UNCITRAL de 1976. II - Parecer ao Consultor Jurídico do Ministério das Relaçōes Exteriores do Brasil, de 09 de novembro de 1984, sobre o Projeto de Convenção sobre Arbitragem Comercial Internacional (Lei-Modelo da UNCITRAL). III - Lei-Modelo sobre Arbitragem Comercial Internacional, adotada pela UNCITRAL na sua 18ª Sessão, em Viena, a 12 de junho de 1985. (Tradução Livre do Autor)
\end{abstract}

RÉSUMÉ: Il s'agit de la présentation en portugais des deux textes élaborés par la Commission des Nations Unies pour le Droit do Commerce International, la CNUDCI, em 1976 (le Règlement sur l'Arbitrage Commercial International) et en 1985 (la Loi-Type sur l'Arbitrage Commercial International). Dans une petite introduction l'auteur étudie l'importance de l'arbitrage international dans les rapports de nature commerciale des nos jours et montre le manque de modernité des lois brésiliennes sur le sujet, même devant les efforts de modernisation de la jurisprudence de la plus Haute Cour du Brésil, pour rendre les sentences arbitrales étrangères valables devant le for brésilien. Il y a aussi la transcription d'un avis de l'auteur dirigé au Ministère des Affaires Étrangères sur le nécessité de rendre la législation brésilienne plus à l'order du jour en ce qu'il s'agît la reglémentation de l'arbitrage commercial international au Brésil. Des notes revoient à des difficultés de terminologie entre les textes de la CNUDCI et droit brésilien.

\section{O DIREITO DO COMÉRCIO INTERNACIONAL E A UNCITRAL}

UNCITRAL (ou sua sigla em francês: CNUDCI) é a United Nations Commision on International Trade Law, comissão de representantes dos Estados junto à ONU, criada pela Resolução n- 2205 (XXI) de sua Assembléia Geral de 17 de dezembro de 1966, e instalação de seus trabalhos na primeira sessão de 29 de janeiro de 1968, com a missão específica de "promover a progressiva harmonização e a unificação do direito do comércio internacional, através de (art. 8º da Resolução AG [XXI] de 17/XII/1966) ações tendentes a: 
a) coordenar o trabalho de organizações ativas neste campo, e encorajar a cooperação entre elas;

b) promover a mais ampla participação nas convenções internacionais já existentes e mais ampla aceitação de leis-modelos e de leis uniformes;

c) preparar e promover a adoção de novas convenções internacionais, leis modelos e leis uniformes, e promover a codificação e mais ampla aceitação de termos do comércio internacional, provisões, costumes e práticas, em colaboração, quando apropriado, com as organizações que operam em tal campo;

d) promover as maneiras e meios de assegurar uma interpretação e aplicação uniformes de convenções internacionais e de leis uniformes no campo do direito do comércio internacional;

e) coligir e disseminar informações sobre legislação nacional e aplicação de convençôes internacionais e de leis uniformes no campo do direito do comércio internacional;

f) estabelecer e manter estreita colaboração com a Conferência das Nações Unidas sobre Comércio e Desenvolvimento, UNCTAD;

g) manter ligações com outros órgãos das Nações Unidas e agencias especializadas, que se dedicam ao comércio internacional;

h) tomar qualquer outra providência que julgar cabível para o cumprimento de suas funções.

O art. 9 da Parte II da referida Resolução assenta as bases normativas do trabalho da UNCITRAL, verbis: "A Comissão levará em consideração os interesses de todos os povos e particularmente aqueles dos países em desenvolvimento, no desenvolvimento extensivo do comércio internacional".

$\mathrm{Na}$ verdade, a UNCITRAL não pretende elaborar um direito internacional "stricto sensu" do comércio internacional, ou seja, um capítulo do Direito Internacional Público dirigido às relações comerciais na atualidade. Tal missāo, que constituiria o que se poderia denominar um "jus mercatorum inter gentes", se perfaz com a elaboração de princípios e normas internacionais, cujos legisladores são os Estados, igualmente seus destinatários, através de tratados internacionais de aplicação supranacional, porque normas supra-estatais; ora são elaborados nas relações bilaterais (tratados de comércio, de navegação, de amizade, de estabelecimento de organismos bilaterais de cooperação econômica e comercial, a exemplo o Tratado de Itaipu, entre Brasil e Paraguai, para o aproveitamento e exploração comercial conjuntos do potencial hidrelétrico do salto de Sete Quedas no rio Paraná), ora nas relações multilaterais regionais, de ma- 
neira direta (tratados de estabelecimento de tratamento preferenciai para produtos oriundos da área definida; a exemplo o Tratado de Cooperação Amazônica) ou de maneira indireta (tratados que criam organismos de integração regional, do tipo ALADI ou das Comunidades Econômicas Européias); ora, enfim, nas relações multilaterais universais (o tratado de estabelecimento do GATT, os que regulam seu funcionamento e os resultados deste, os acordos de Bretton Woods de criação do FMI e do BIRD, as criaturas das Nações Unidas, do tipo UNCTAD, PNUD, etc.).

A atuação dos agentes do que denominamos "jus mercatorum inter gentes" tem em vista criação de normas auto-aplicáveis pelos Estados, uma vez que normas de Direito Internacional Público. Tão somente como retórica se pode falar, neste campo, de criação de um Direito Uniforme, e muito menos de coordenação de aplicação de leis modelos ou regulamentos de direito material uniformizados.

Na UNCITRAL, trata-se, isto sim, da elaboração de um "jus gentium mercatorum", direito que regula as relaçōes dos agentes do comércio internacional, e que tendem a ser uniformizados no mundo, não por força de constarem em tratados internacionais, mas pela sua própria vocação de ultrapassarem as fronteiras dos Estados. O fato de a denominada "lex mercatoria" já ter existido com o nome de "jus gentium", conforme bem apontou o Prof. Berthold Goldmann apud "lex Mercatoria" in Forum Internationale, no 3, nov. 1983 (Kluwer, Daventer, Países Baixos), mostra que não se trata de um mero capítulo do Direito Internacional Público, mas antes, de um ramo novo do direito, o Direito do Comércio Internacional, cuja tipicidade pode ser demonstrada tão só pelo estudo de suas fontes normativas. Neste campo, ganham em relevância os usos e costumes do comércio internacional, que se sobressaem em importância sobre o "jus scriptum", este, na verdade, mais compilações do que verdadeiras fontes legislativas (veja-se, a exemplo, a compilação dos INCOTERMS feita pela Câmara Internacional do Comércio de Paris, a prestigiada CCI, organização de caráter privado de direito francês, que no entanto, são aceitos como normas cogentes nas relaçōes comerciais internacionais, ou ainda a Convenção da Haia de 15 de junho de 1964, relativa ao Direito Uniforme em Matéria de Formação de Contratos para a Venda Internacional de Bens Móveis Corpóreos, que tem sido aplicada como lei supletiva nos contratos comerciais internacionais). A inexistência de um legislador internacional que tenha o poder de elaborar normas uniformes que regulem as relações de caráter privado no comércio internacional, torna o estudo do direito do comércio internacional bastante complexo, pois exige um conhecimento das normas do Direito Internacional Público, da atuação dos organismos interestatais, bem como daquele terreno vastíssimo dos usos e costumes vigentes nas relaçōes comerciais entre particulares submetidos a jurisdiçōes estatais diferentes. 
No relatório do Secretário Geral da ONU, por ocasião da votação da Resolução da AG que criou a UNCITRAL, a expressão "direito do comércio internacional" foi definida como "o corpo de normas que regulam as relaçōes comerciais de caráter privado, que envolvem diferentes países" e que englobam:

a) compra-e-venda internacional de mercadorias (intl. sale of goods)

i) formação dos contratos;

ii) acordos de agenciamento;

iii) acordos de exclusividade de vendas.

b) instrumentos negociáveis e créditos bancários comerciais;

c) normas relativas à conduta de atividades negociais referentes ao comércio internacional;

d) seguro;

e) transporte:

i) transporte de mercadorias por mar;

ii) transporte de mercadorias por via aérea;

iii) transporte de mercadorias por estradas de ferro e rodovias;

iv) transporte de mercadorias por águas interiores.

f) propriedade industrial e direitos autorais;

g) arbitragem comercial.

No citado relatório, foi afirmado ( $\S 11$ ) que o que então se discutia, na criação da UNCITRAL, não era pertinente às "relações comerciais internacionais ao nível do direito público (on the level of public law), como aquelas relativas às atitudes e comportamentos dos Estados, quando regulamentam, no exercício de sua soberania, a conduta do comércio que afeta seus territórios. Ilustraçōes de relações comerciais de tal tipo são os tratados bilaterais ou multilaterais de comércio, tais o GATT, ou o Tratado de Roma que estabeleceu a Comunidade Econômica Européia. Os acordos internacionais sobre produtos de base ("international commodity arrangements") estão igualmente excluídos do presente relatório...

O que tem caracterizado a formação do direito do comércio internacional é seu caráter espontâneo, baseado nos usos e costumes das relaçōes mercantis internacionais, entre pessoas submetidas a leis de Estados diferentes, e com 
grande número de normas "secretadas" pela jurisprudência arbitral internacional. Com efeito, inexiste um judiciário institucional com uma competência prévia aos litígios e com uma jurisdição internacional em qualquer parte do mundo, no que se refere às relaçōes do comércio internacional, (comércio entendido "strico sensu", como as relações de caráter privado entre pessoas submetidas a jurisdições estatais distintas) $)^{(1)}$ Mesmo que se admita um desdobramento de funçōes do juiz judiciário de cada Estado, de ser também um órgão judiciário internacional quando julga questões que envolvem pessoas submetidas a jurisdições estatais diferentes (a teoria do "dédoublement fonctionnel" do Prof. Georges Scelle), o fato é que as relações comerciais internacionais têm uma incompatibilidade com os judiciários internos; são exatamente as virtudes dos judiciários internos (a publicidade, o relativo formalismo rígido imposto pelo legislador nacional no caminhar-se no processo civil, os poderes absolutamente fixos e inalteráveis do julgador, funcionário do Estado, as limitaçōes de soluções negociadas entre os litigantes durante o processo) que tem causado a busca de soluções de litígios entre participantes dos negócios comerciais internacionais, em formas mais expeditas, rápidas, secretas e cercadas com formalidades mínimas, e sobretudo, com procedimentos que as partes podem controlar; uma delas é a arbitragem comercial internacional.

\section{A Arbitragem Comercial Internacional e Suas Fontes Normativas}

Como qualquer fenômeno relacionado ao comércio internacional, a arbitragem comercial internacional repousa sobre a quase total autonomia das vontades dos agentes. As normas que regulam as relações jurídicas são, na maioria dos casos, elaboradas pelas partes e retiram sua eficácia da boa fé que rege aqueles relacionamentos; a prática internacional, aliada à noção psicológica de sua obrigatoriedade, constituem os usos e costumes do comércio internacional, extremamente espontâneos e próximos dos fenômenos que regulam, mas, de difícil prova. As normas escritas que os Estados elaboram no comércio internacional (evidentemente que estamos excluindo as normas estatais internas, unilaterais, que algumas vezes podem regular o comércio internacional), na forma de tratados de uniformização de normas de natureza privada, tentam respeitar o caráter jurígeno das vontades dos agentes do comércio internacional e assim devem ser interpretadas. Na sua maioria são normas supletivas à vontade das partes.

(1) Nas relações comerciais em que os Estados direta ou indiretamente participam, o caráter privado das relações não desaparece por completo. Veja-se nos problemas relacionados com os temas dos contratos internacionais com o Estado, arbitragens internacionais entre Estados e particulares, as questões das imunidades de jurisdição e de execução e as tentativas de eliminarem-se posiçōes privilegiadas dos Estados quando integram relações que um simples particular pode integrar. 
A arbitragem comercial internacional é uma jurisdição negocial, instituída por um pacto entre as partes, basicamente em dois momentos: a) no momento em que se concerta um negócio, em que todas as coisas são róseas e que portanto, inexiste litígio aparente entre os parceiros; mesmo assim, as partes podem prever a solução arbitral para aquele negócio (cláusula compromissória em qualquer tipo de contrato) ou, num pacto especial, colocar todos os outros contratos ou negócios dentro da solução arbitral prevista para um futuro imprevisível (pactos de arbitragem); b) no momento em que surge uma controvérsia real, e que as partes não podendo resolvê-la por elas mesmas, confiam a solução ao(s) árbitro(s), seja colocando em funcionamento os pactos arbitrais anteriormente elaborados, seja construindo um tribunal "ad hoc", através de um contrato especial, o compromisso arbitral. A instituiçāo da arbitragem pode ser feita, igualmente de duas maneiras: a) "ex nihilo", criando mecanismos de constituição do tribunal arbitral, dando-lhe competências, construindo um código de procedimento para os árbitros e os litigantes, estabelecendo as leis que os árbitros deverão aplicar; b) através de um mecanismo de incorporação de normas já existentes, transformar estas em normas que regulem todos os incidentes na arbitragem. Neste último particular, a criação ex nihilo tem a desvantagem de poder contar com grande lacunas, pois, em particular, quando existe 'já uma situação de conflito de interesses, muito dificilmente as partes terão condição de imaginar o funcionamento de um tribunal, com todos os pormenores.

Por outro lado, a força normativa dos usos e costumes no comércio internacional faz com que as normas já elaboradas e aceitas pela comunidade dos agentes dos negócios internacionais se imponham às partes. Em particular, nos contratos internacionais, a grande preocupação dos negociadores é com o regime jurídico que irá regular o mesmo, nos seus vários aspectos; o que se observa é que as partes elegem uma lei, ou várias leis, para regular todo o contrato ou pedaços dele; tais leis podem ser leis estatais escritas, ou os "usos e costumes comerciais da praça de---", ou ainda, leis não estatais, do tipo, "usos e costumes reguladores do presente negócio".

Ora, a grande dificuldade que os usos e costumes comerciais internacionais representam é de sua existência e seu conteúdo. Neste particular, ressaltase a importância da jurisprudência arbitral, não só como fonte nas lacunas, como sobretudo como instrumento de aclaramento de um costume internacional. Sendo dado que é norma costumeira nos contratos internacionais a previsão de soluções arbitrais, e tendo em vista a existência de normas já elaboradas por organizações especializadas em arbitragens comerciais internacionais, segue-se que é praxe no comércio internacional as soluçōes arbitrais nos negócios internacionais, com grande tendência à incorporação das normas existentes por organismos mencionados.

Contudo, a incorporação por referência de um contrato a normas já existentes e elaboradas por aqueles organismos, não esgota a criatividade dos par- 
ceiros em negócios internacionais, uma vez que na matéria prevalece a autonomia das vontades, sendo as normas existentes, na sua maioria, de caráter supletivo. Assim, é de observar-se nos regulamentos de arbitragem internacional existentes hoje, a abundância de redação de normas da seguinte forma: "salvo estipulação em contrário das partes", "com reserva do que dispuser os litigantes"...; é nosso pensamento que, mesmo que não haja semelhantes reservas nos textos legislativos, pela natureza do assunto, são elas normas supletivas, que só têm aplicação, na ausência da manifestação da vontade das partes.

Os tratados internacionais interestatais que regulam a arbitragem comercial internacional são obrigações dirigidas aos Estados no sentido de eles reconhecerem efeitos às normas relativas às arbitragens, e tem sentido muito mais no que se refere às legislações internas dos mesmos do que propriamente ao regime das arbitragens comerciais internacionais. Deixando de lado o mumificado Protocolo de Genebra de 1923, relativo a cláusulas de arbitragem vigente só no Brasil uma vez que foi abrogado pela Convenção da ONU de Nova York de 1958, "para o reconhecimento e execução de sentenças arbitrais estrangeiras"(2), pode-se observar que os tratados internacionais de Direito Processual Internacional que se tornam obrigatórias para os Estados signatários: a) cria-se a obrigação ao Estado de reconhecer e dar executoriedade a laudos arbitrais estrangeiros; b) cria-se a obrigação de reconhecer os efeitos da arbitragem e enviar as partes litigantes aos árbitros, subtraindo-lhes a via judicial, antes de esgotado aquele recurso; c) estabelecem as condiçōes mínimas para dar-se o reconhecimento e a exeqüibilidade a laudos arbitrais estrangeiros; $d$ ) as condiçōes de controle de legalidade das arbitragens: segundo as leis de regência da arbitragem, o respeito ao contraditório arbitral, os limites objetivos e subjetivos da "res judicata" arbitral, a definitividade do laudo arbitral estrangeiro, (conforme os termos da mencionada Convenção da ONU de Nova York, que, "mutatis mutandis" são repetidos nas Convenções do Panamá (arbitragem interamericana) e Genebra (convenção européia).

Isto posto, ressalta claro que as fontes normativas das arbitragens comerciais internacionais são representadas pela vontade dos contratantes, pelos usos e costumes do comércio internacional, pelas normas elaboradas nos organismos de natureza privada e profissionais, como as câmaras de comércio, a Comissão de Arbitragem da CCI, e as inúmeras organizações arbitrais especializadas, tais a AAA (American Arbitration Association, com sede em Nova York), a London Corn Trade Association, a "Verein am der Caffeehandel beteiligten Firmen zu Hamburg", etc.

(2) Vigente na maioria dos países da atualidade, contando-se na América: Canadá, Chile, Colombia, Cuba, Equador, EUA, Guatemala, Haiti, México, Panamá, Trinidad e Tobago e Uruguai. 
As partes que desejam submeter-se à arbitragem de uma dessas intituições, ou fazem remissão às suas normas nas cláusulas compromissórias de seus contratos, ou nos contratos gerais de arbitragem, ou ainda, subscrevem atos específicos de submissão (na CCI é o "acte de mission" ou "terms of referee"). Por outro lado, o fato de já existirem regulamentos em tais instituições, não lhes confere a natureza de normas inderrogáveis pelas partes, as quais podem modificá-las, dentro dos limites razoáveis (respeitando-se o princípio de que as regras procedimentais não podem ser alteradas, quando já colocadas em funcionamento, a não ser pela vontade das partes e do tribunal arbitral).

Ora, é dentro da grande autonomia das partes que se coloca o esforço da UNCITRAL, na elaboraçāo de um Regulamento de Arbitragem, e é dentro da liberdade legislativa que têm os Estados em regular assuntos internos relativos à arbitragem internacional, que aqueles esforços de uniformização das normas sobre $\mathrm{o}$ assunto se situam.

\section{O Regulamento de Arbitragem de 1976 e a Lei-Modelo de 1985}

De tudo que se disse sobre a arbitragem comercial internacional, em particular sobre suas fontes normativas, levanta-se uma objeção: qual a finalidade de elaborar-se um Regulamento por um organismo diplomático internacional, como a UNCITRAL, uma vez que as fontes normativas não são susceptíveis de ser reguladas por açöes diretas dos Estados! Qual utilidade de elaborar-se uma Lei-Modelo sobre Arbitragem Comercial Internacional!

Em primeiro lugar, os regulamentos de arbitragem existentes foram elaborados por organismos profissionais postados em um país do mundo; os mais famosos em Paris, Londres, Hamburgo, Estocolmo e Nova York, alguns dedicados a matérias específicas do comércio internacional (comércio de cereais, café, seguros marítimos, etc.). $O$ universalismo na elaboração das normas de um regulamento internacional da arbitragem comercial internacional explica a ação da UNCITRAL: pode-se pensar em colocar as mesmas normas aplicáveis nas relações entre países de economia de mercado e países de economia centralmente planificada; da mesma forma, é mais viável uma aproximação de normas de sistemas diferentes como os da "commom law" e do sistema romano-germânico quando as normas uniformes foram elaboradas em conjunto (num foro como o da UNCITRAL); por fim, a aceitação de normas uniformes saídas de um foro internacional "ex novo" é mais praticável, pelos jovens países do terceiromundo do que aquelas já existentes no velho mundo. Além do mais, o Regulamento de arbitragem da UNCITRAL foi elaborado após exaustivas consultas entre Governos, entidades especializadas em arbitragem e peritos mundiais: é bem provável que reflita um universo mais ou menos de aceitação generalizada no mundo. 
Tanto o Regulamento quanto a Lei-Modelo não são atos normativos, por força deles mesmos. No primeiro caso, são normas ideais que podem regular qualquer relação entre pessoas de direito privado submetidas a leis de Estados diferentes, em matéria de arbitragem comercial internacional. Tanto podem ser aplicadas diretamente pelas paries (no caso de instituição de um tribunal arbitral "ad hoc") quanto por uma organização já existente (e nesse caso, passam a reger as relações entre os litigantes, em derrogação das normas já existentes no interior de tais organizaçōes). De particular interesse é o Regulamento da UNCITRAL nas relações comerciais na América Latina.

A Convenção Interamericana sobre Arbitragem Comercial Internacional, feita na cidade do Panamá em 30 de janeiro de 1975, já em vigor entre os Países que a ratificaram (Chile, Costa Rica, El Salvador, Honduras, México, Panamá, Paraguai, Uruguai e Venezuela) a qual o Brasil e os EUA assinaram (sendo que neste País já houve aprovação do Senado norte-americano, faltando o seu Congresso passar legislação interna de aprovação), estabelece no seu art. 3- que "na falta de acordo expresso entre as partes, a arbitragem será efetuada de acordo com as normas de procedimento da Comissão Interamericana de $\mathrm{Ar}$ bitragem Comercial", sendo que esta adotou o Regulamento da UNCITRAL, como as mencionadas normas de procedimento.

Outro exemplo da importância do Regulamento da UNCITRAL foi sua adoção pelo acordo concluído em janeiro de 1977 entre a "American Arbitration Association", a Câmara de Comércio e de Indústria da URSS e a Câmara de Comércio de Estocolmo, (esta última, especializada nas arbitragem com países do Leste Europeu) conforme informa o Prof. Philippe Fouchard no seu artigo "Les Travaux de la C.N.U.D.C.I. - Le Règlement d'Arbitrage", in Journal du Droit International, 1979, no 4, p. 816/845.

Sua utilidade maior, contudo, reside no fato de ser um regulamento modelo, bem equilibrado e concebido, que reflete as tendências mais generalizadas e mundialmente aceitas na atualidade. No Brasil, em época anterior, foi instituída a Comissão de Arbitragem da Câmara de Comércio Brasil-Canadá, por volta de 1975, portanto antes da existência do Regulamento da UNCITRAL; seu regulamento de arbitragem, elaborado com o maior cuidado por grandes advogados de São Paulo, em que pese os esforços de aperfeiçoar o regulamento da CCI, que lhe serviu de modelo, contem lacunas que seriam evitáveis se fosse possível ter seguido o modelo do regulamento da UNCITRAL. Sendo dado que a tendência contemporânea é o crescimento e espraiamento das arbitragens comerciais (internas e internacionais) no mundo, é bem possível que o Regulamento da UNCITRAL realize aquela uniformização do direito que pretende aquela comissão da ONU.

O texto do Regulamento de Arbitragem da UNCITRAL constitui o ANEXO-I do presente trabalho, que apresentamos em nossa tradução para o verná- 
culo, dada a importância de um texto que não se acha publicado no Brasil. Se ainda não bastasse a relevância do conhecimento do mesmo para os interessados em arbitragem comercial internacional, seja estudiosos, seja homens de negócios, é o mesmo um material didático utilizado, a miúde, nas disciplinas sob nossa responsabilidade nesta Faculdade de Direito da Universidade de São Paulo: nos Cursos da Graduação, "Direito do Comércio Internacional", e "Arbitragens Internacionais" e nos Cursos de Pós-Graduação em Direito Internacional, "Teoria Geral das Arbitragens Internacionais" e "Arbitragem Comercial Internacional".

Outro importante trabalho da UNCITRAL foi a elaboração da LEI MODELO SOBRE ARBITRAGEM COMERCIAL INTERNACIONAL, adotada na XVIII Sessão, realizada em Viena de 3 a 21 de junho de 1985, de cuja notícia fomos informados pelo Relatório do Chefe da Delegação brasileira àquela reunião, o ilustre Prof. Dr. Luiz Gastão Paes de Barros Leães, publicado in Revista de Direito Mercantil, Industrial, Econômico e Financeiro, Ano XXIV (Nova Série), no 60, outubro/dezembro de 1985, p. 66/82, apud "Atualidades: Lei-Modelo de Arbitragem Comercial Internacional", que traz o texto da mencionada Lei-Modelo.

Já anteriormente à reunião da sessão de aprovação da Lei-Modelo, éramos solicitados pelo Consultor Jurídico do Ministério das Relações Exteriores do Brasil, o eminente Prof. Dr. Miguel Franchini-Netto, igualmente Representante Permanente do Brasil junto à UNCITRAL, a emitir um Parecer sobre o Projeto de Convenção sobre Arbitragem Comercial Internacional - (Lei-Modelo da UNCITRAL), "tendo em vista a legislação interna e o interesse nacional". Nossa opinião foi exarada no Parecer encaminhado àquela Autoridade, em 09 de novembro de 1984, em Parecer que constitui o ANEXO-II do presente trabalho.

É um texto complexo, o da Lei-Modelo, uma vez que trata de dois assuntos: a) um regulamento da arbitragem comercial internacional (e nesses particular, repete os conceitos do Regulamento da UNCITRAL de 1976, nos seus dispositivos inatacáveis) e b) dispositivos recomendados aos Estados, de Direito Processual Civil, no que respeita ao tratamento a ser dado à arbitragem nas legislações internas.

Ora, um dos maiores problemas relativos à arbitragem comercial internacional é seu tratamento nas duas fases mais importantes daquele procedimento negocial de solução de litígios: a fase inicial, de constituição do tribunal arbitral e do afastamento da via judiciária, e a fase pós-arbitral, de execução compulsória da sentença arbitral, feita perante os órgãos do Poder Judiciário dos Estados. Na verdade, tais assuntos são antes, como já se disse anteriormente, 
problemas relacionados aos Direitos Processuais Civis dos Estados, matéria extremamente difícil de ser harmonizada, e sobretudo uniformizada por normas internacionais, devido a reportar-se a assuntos dos mais ferrenhamente ligados à noção de soberania dos Estados, matérias reservadas à competência interna dos mesmos, extremamente ligadas à própria organização constitucional dos Estados.

O texto é ainda mais complexo, se levarmos em consideração que versa sobre uma lei-modelo, que deve comportar todas as possibilidades de ser adotada em sistemas distintos, seja de famílias normativas (commom law, o sistema romano-germânico, os direitos ideológicos do Leste Europeu, da China e Cuba, os direitos religiosos do tipo muçulmano, ou animista) seja de Estados com desenvolvimento econômico distinto, seja ainda divididos entre as concepções de, regidos por uma economia de mercado ou centralmente planificados. Ademais, deve tal lei-modelo comportar soluçōes alternativas de molde a satisfazer as inumeráveis diferenças dos sistemas judiciários de processo civil, quanto ao regime de atribuir-se eficácia executória a sentenças arbitrais (e para complicar mais o cenário, ainda com a diferenciação entre sentenças arbitrais nacionais e sentenças arbitrais estrangeiras, para não dizer, ainda, sentenças arbitrais verdadeiramente internacionais).

Embora o documento e seus comentadores sempre digam, com ênfase, que se trata de um texto, que não é ele mesmo normativo, uma vez que lei-modelo a servir de quadro referencial para os legisladores internos, sua aprovação pela UNCITRAL já representa importância transcendental no assunto: é um modelo que reflete uma concepção majoritária dos Governos que encaminharam sua adoção naquela Comissão das Naçōes Unidas; elaborado que foi por especialistas mundiais, reflete um consenso científico sobre a matéria; em que pese a dificuldade de realização de seus propósitos de unificar os direitos internos em matéria de arbitragem comercial internacional, representa um auxiliar poderoso para o intérprete das normas de direito do comércio internacional ${ }^{(3)}$.

Outra curiosidade no texto da lei-modelo da UNCITRAL se refere à nota de rodapé do mesmo. Os comentadores-redatores do texto da Lei-Modelo, conforme "Report of the UNCITRAL on the Work of its 18th. Session (June 3-21, 1985) apud UN. General Assembly, Official Records, 40th. Session, Suppe-

(3) Salvo para os historiadores do direito, o socílogo do direito, o filbsofo, os textos não vigentes (por não terem sido aprovados ou por terem sido derrogados) pouca importância têm para o exegeta, na realidade interna dos Estados. Não é o que se passa nas relações internacionais, onde um texto vigente na maioria dos Estados, ou na esfera internacional, sem estar formalmente vigente na esfera interna, representa normatividade, pelo menos corno prova da existência de um costume internacional. 
ment $n \div$ 일. Chapter II, pp. 5/65, publiçado em I.L.M. 1985, p. 1314/1368, reconhecem ser inusitado que um texto legal contenha uma nota de rodapé; contudo, como se trata de uma lei-modelo que serve de parâmetro ao legislador interno, e como há sistemas jurídicos que permitem a edição de textos normativos com as mencionadas notas de rodapé, preferiram deixar a matéria no referencial do rodapé e não no texto mesmo da lei.

É exatamente no citado rodapé que existe a seguinte afirmação, de importância para definir-se a matéria própria de um Direito do Comércio Internacional, bem mais abrangente e clara que aquela definição existente no Relatório do Secretário Geral da ONU por ocasião da votação da Resolução da AG que criaria a UNCITRAL, (anteriormente mencionada), verbis:

The term "commercial" should be given a wide interpretation so as to cover matters arising from all relationships of a commercial nature, whether contractual or not. Relationships of a commercial nature include, but are not limited to, the following transactions: any trade transaction for the supply or exchange of goods or services; distribution agreement; commercial representation or agency; factoring; leasing; construction of works; consulting, engeneering licensing; investment; financing; banking; insurance; exploitation agreement or concession; joint venture and other forms of industrial or business co-operation, carriage of goods or passengers by air, sea, rail or road.

Isto posto, uma das discussões mais acirradas em matéria de arbitrabilidade de litígios, se só admissível a solução arbitral internacional para matérias comerciais (requisito que o Brasil exigiu quando ratificou o pré-histórico Protocolo de Genebra de 1923 sobre cláusulas de arbitragem), qual o foro de definição, se o arbitral ou se o judicial - onde se pede tornar a sentença arbitral um titulo executório, quais os critérios de qualificação, etc., acha-se em princípio, encaminhado em solução, pela definição, inda que de normatividade discutível, na citada Lei-Modelo da UNCITRAL, pelo menos como um conceito de aceitação naquela Comissão da ONU, de peso comparável à doutrina ou aos princípios gerais do direito do comércio internacional.

\section{CONCLUSŌES}

São significativas as palavras iniciais do artigo já referido do Prof. Philippe Fouchard no seu "Les Travaux de la C.N.U.D.C.I. - Le Règlement d'Arbitrage", publicado no Journal du Droit International de 1979, no 4, pp. $816 / 845$ de que "objet de la sollicitude des Organisations internationales les plus diverses, l'arbitrage est aussi 'I'enfant gâté" de l'Organisation des Nations Unies (itálicos adicionados). Na verdade,se hoje é impressionante o 
número de congressos internacionais sobre a arbitragem comercial internacional, se é o tema que mais estudos têm merecido dos especialistas do Direito do Comércio Internacional, se sua importância tem exigido esforços diretos da ONU, como prova o trabalho da UNCITRAL, nada mais prova do que a importância do tema e a relevância do instituto, na solução dos problemas diuturnos nas relaçōes comerciais internacionais mais importantes, aqueles que interligam pessoas de direito privado, submetidas a sistemas legislativos estatais diferentes. No fundo, é a exigência prática a causa determinadora da importância mencionada.

Nāo poderia o Brasil ficar à parte do movimento internacional de prestigiamento da arbitragem, seja nas relações comerciais internas, seja nas relações do comércio internacional, do qual depende de maneira vital.

Com uma legislação processual civil interna completamente inadequada a regular as arbitragens internas e internacionais, e que permita ao País responder aos desafios das mudanças rápidas verificadas na configuração dos negócios internacionais da atualidade, o Brasil tem sentido a necessidade de adequar seu direito interno às realidades contemporâneas. Um dos indícios podem ser apontados como as reformas pretendidas do Código de Processo Civil brasileiro, no capítulo das arbitragens, conforme expusemos em nossa obra Órgãos das Soluções Extrajudiciárias de Litígios, Ed. RT, São Paulo, 1985 (em particular, no Apêndice). Todavia, mesmo antes dos movimentos de reformas legislativas, a Academia se antecipou ao estudo das arbitragens comerciais internacionais, pois, na primeira oportunidade que lhe foi dada, a Faculdade de Direito da Universidade de São Paulo introduziu nos seus currículos, ao nível da formação básica de seus estudantes, no Curso de Graduação, a disciplina "Arbitragens Internacionais", bem como tem aberto a discussão do tema nos Cursos de Pós-Graduação, como já se mencionou.

Dois trabalhos importantes foram apresentados pelos Professores da Faculdade de Direito do Largo de São Francisco, em época recente sobre o tema: a dissertação de mestrado da Professora Araminhta de Azevedo Mercadante, "Contribuição ao Estudo da Arbitragem Comercial Internacional: A Convenção Arbitral", defendida em 1979, e a tese de doutorado pelo então Mestre José Carlos de Magalhães, "Arbitragem entre Estado e Particular Estrangeiro", defendida em 1983, e que está para ser publicada com o título Do Estado na Arbitragem Privada. Outra prova do interesse e vigor do tema nos meios científicos foi a publicação em 1986, da 1a edição do livro Arbitragem Comercial, de autoria conjunta dos Professores daquela Faculdade de Direito, José Carlos de Magalhães e Luiz Olavo Baptista, Rio de Janeiro, Freitas Bastos.

O tema é de real interesse nas relações comerciais internacionais em que empresários e homens de negócios brasileiros estejam envolvidos, sem dizer do interesse científico e pedagógico do mesmo, razões pelas quais pretendemos voltar ao assunto nesta Revista. 


\section{BIBLIOGRAFIA}

FOUCHARD, Philippe "Les Travaux de la C.N.U.D.C.I. - Le Règlement d'Arbitrage", CLUNET, 1979, no 4, pp. 816/845.

GOLDMAN, Berthold "Les Travaux de la Commission des Nations Unies pour le Droit Commercial International”, CLUNET, 1979, n 4, pp. 747/754.

. "Lex Mercatoria" in Forum International, n 3, nov. 1983, pp. 3/24, Kluwer Law and Taxation Pub., Deventer, Países Baixos.

LEÃES, Luiz GAstão de Barros "Lei-Modelo de Arbitragem Comercial Internacional" in "Atualidade", Revista de Direito Mercantil, Industrial, Econômico e Financeiro, São Paulo, ano XXIV (Nova Série), no 60, out./dez. 1985, pp. 66/82.

MAGAlHÃES, José Carlos de Arbitragem entre Estado e Particular Estrangeiro, tese de doutoramento, apresentada e defendida na Faculdade de Direito da Universidade de São Paulo, em 1983.

(no prelo).

- Do Estado na Arbitragem Privada, São Paulo, Max Limonad

MAGALHÃES, José Carlos de, e Luiz Olavo Baptista Arbitragem Comercial, Rio de Janeiro, Ed. Freitas Bastos, 1986.

MERCADANTE, Aramintha de Azevedo Contribuição ao Estudo da Arbitragem Comercial Internacional: A Convenção Arbitral, monografia de mestrado apresentada à Faculdde de Direito da Universidade de São Paulo, e defendida em 1979.

SOARES, Guido Fernando Silva Órgãos das Soluções Extrajudiciárias de Litígios, Ed. Revista dos Tribunais, São Paulo, 1985.

United Nations Commission on International Trade Law, "UNCITRAL Report on the Work of its 18th. Session (June 3.21, 1985), apud International Legal Materials, 1985, pp. 1314/1368.

1971.

Yearbook, vol. 1. 1969/1970, Nova York, United Nations, 
ANEXO - I (Tradução livre do autor)

\section{REGULAMENTO DE ARBITRAGEM DA UNCITRAL ${ }^{(4)}$}

Resolução 31/98 adotada pela Assembléia Geral, em 15 de dezembro de 1976.

31/98. Regulamento de Arbitragem da Comissão das Nações Unidas para o Direito Comercial Internacional.

\section{A Assembléia Geral,}

Reconhecendo a utilidade da arbitragem como método de resolução de litígios nascidos de relações comerciais e internacionais;

Convencida de que o estabelecimento de um regulamento de arbitragem "ad hoc", que seja aceitável nos países que tenham sistemas jurídicos, sociais e econômicos diferentes, contribuiria sensivelmente para o desenvolvimento de relações econômics internacionais harmoniosas;

Consciente de que o Regulamento de Arbitragem da Comissão das Naçōes Unidas para o Direito Comercial Internacional foi elaborado, após consultas exaustivas a instituiçōes de arbitragem e aos centros de arbitragem comercial internacional;

Notando que o Regulamento de Arbitragem foi adotado pela Comissão das Nações Unidas para o Direito Comercial Internacional na sua nona sessão, após aprofundadas deliberações,

1. Recomenda a aplicação do Regulamento de Arbitragem da UNCITRAL para a solução de litígios nascidos de relações comerciais internacionais, particularmente pela referência ao Regulamento de Arbitragem, feita nos contratos comerciais;

2. Pede ao Secretário Geral assegurar a difusão mais ampla possível do Regulamento de arbitragem.

(4) Conforme: Règlement d'Arbitrage de la CNUDCI, Nações Unidas, Nova York, 1977 (fascículo à venda) (nota do tradutor). 


\section{REGULAMENTO DE ARBITRAGEM DA UNCITRAL Seção I - Disposições Preliminares \\ Campo de Aplicação

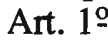

1. Se as partes em um contrato convencionarem, por escrito ${ }^{(5)}$, que os litígios relativos a tal contrato,serão submetidos à arbitragem conforme o Regulamento da UNCITRAL, tais litígios serão resolvidos segundo o presente Regulamento, sob reserva das modificações convencionais por escrito entre as partes.

2. O presente Regulamento regula a arbitragem, sob a reserva, contudo, de que, no caso de conflito entre uma de suas disposiçōes e outra da lei aplicável à arbitragem, que as partes não podem derrogar, prevalecerá esta última.

\section{Notificação, Contagem de Prazos}

Art. 2 -

1. Para os fins do presente Regulamento, uma notificação, inclusive uma comunicação ou proposta, é considerada como tendo chegado ao seu destino, se for entregue, seja em mãos do destinatário, seja na sua residência habitual, no seu estabelecimento ou no seu endereço postal, seja ainda - se nenhum desses endereços puder ser encontrado, após uma razoável busca - na última residência ou no último estabelecimento conhecido do destinatário. A notificação é tida como chegada no lugar de destino, no dia de sua entrega.

2. Para os fins de contagem de prazo previsto no presente Regulamento, começará o mesmo a correr no dia em que a notificação, comunicação ou proposta chegar ao seu destino. Se o último dia do prazo for feriado no lugar da residencia ou do estabelecimento do destinatário, o prazo será prorrogado para o primeiro dia útil que se seguir. Os dias feriados que se encontram dentro do prazo, ̃o contados.

(5) Redação-tipo de cláusula compromissória:

"Qualquer litígio, controvérsia ou reclamação oriundos do presente contrato, ou que se refiram ao presente contrato, ou a uma contravenção ao presente contrato, à sua resolução ou nulidade, serão resolvidas pela via arbitral, conforme o Regulamento de Arbitragem da UNCITRAL, atualmente em vigor.

Nota. As partes poderão, ainda, adicionar as seguintes indicaçōes:

a) A autoridade para a nomeação será... (nome da pessoa ou instituição);

b) O número dos árbitros será fixado em... (um ou três);

c) A sede da arbitragem será... (cidade ou país);

d) A língua (ou línguas) utilizada(s) no procedimento arbitral será (serão)... 


\section{Notificação de Arbitragem}

Art. 39

1. A parte que tiver a iniciativa de recorrer à arbitragem (doravante denominada: "requerente") deverá comunicar à outra parte (doravante denominada: "requerido") uma notificação de arbitragem.

2. O procedimento da arbitragem é tido como iniciado, na data em que a notificação de arbitragem for recebida pelo requerido.

3. A notificação de arbitragem deve conter as seguintes indicações:

a) pedido para que o litígio seja submetido à arbitragem;

b) nomes e endereços das partes;

c) menção da cláusula compromissória ou da convenção separada de arbitragem invocada ${ }^{(6)}$;

d) menção do contrato do qual se originou o litígio ou ao qual se refira;

e) a natureza geral do litígio e, se for o caso, uma estimativa da quantia sobre o qual ele versa;

f) o objeto da demanda;

g) a proposta quanto ao número dos árbitros (ou seja, um ou três), na falta de acordo prévio sobre tal ponto entre as partes.

4. A notificação de arbitragem poderá conter, igualmente, as seguintes indicações:

a) as propostas referentes à indicação de um árbitro único e de uma autoridade de nomeação, contempladas no art. 60, parágrafo único;

b) a notificação da nomeação de um árbitro, conforme o art. 7;

(6) "convention distincte d'arbitrage invoquée": trata-se de um pacto onde haja previsão expressa de arbitragem, seja do tipo: contrato de compromisso arbitral ("ad hoc", para um determinado litígio presente); seja do tipo: pacto geral de arbitragem (em que se pactua, no futuro, para tais ou quais negócios, a solução arbitral, sendo, assim, não meras cláusulas adjetas a outros contratos mas um contrato de arbitragem, obrigação de fazer (aspectos positivos) e de abster-se de recorrer a quaisquer outras vias, inclusive a judiciária (aspectos negativos) (Nota do tradutor). 
c) o pedido, conforme o art. 18 .

\section{Representação e Assistência}

Art. $4^{\circ}$

As partes podem fazer-se representar ou assistir por pessoas de sua escolha. Os nomes e endereços de tais pessoas devem ser comunicados por escrito à outra parte; tal comunicação deve precisar se a designação é feita com vistas a uma representação ou assistência.

\section{SEÇÃO II - COMPOSIÇÃO DO TRIBUNAL ARBITRAL Número de Árbitros}

Art. 5o

Se as partes não convieram anteriormente sobre o número de árbitros (ou seja, um ou três) e se, nos quinze dias decorridos da recepção pelo requerido da notificação da arbitragem, as partes não tiverem acordado que haverá um único árbitro, serão nomeados três árbitros.

\section{Nomeação dos Árbitros (art. 6 a 8)}

Art. 60

1. Se um único árbitro deve ser nomeado, cada parte poderá propor à outra:

a) o nome de uma ou várias pessoas susceptíveis de exercer as funçōes de árbitro único; $\mathrm{e}$

b) se nenhuma autoridade de nomeação foi escolhida pelas partes de comum acordo, o nome de uma ou várias instituiçōes ou de pessoas susceptíveis de exercer as funções de autoridade de nomeação.

2. Se, nos trinta dias da recepção por uma parte de uma proposta feita segundo o $\S 1^{\circ}$, as partes não se colocarem de acordo sobre a nomeação de um árbitro único, este será nomeado pela autoridade de nomeação escolhida pelas partes de comum acordo, ou, se a autoridade de nomeação por elas escolhida se recusar a agir ou não nomear o árbitro dentro dos sessenta dias da recepção de pedido de uma parte em tal sentido, cada parte poderá solicitar ao Secretário Geral da Corte Permanente de Arbitragem da Haia de designar uma autoridade de nomeação.

3. A autoridade de nomeação, a pedido de uma das partes, nomeará o árbitro único o mais rapidamente possível. Deverá proceder a essa nomeação, utilizan- 
do-se do sistema de listas, conforme o procedimento a seguir descrito, a menos que as partes não se tenham entendido no sentido de afastar tal procedimento, ou que a autoridade de nomeação julgue, no exercício de seu poder de apreciação, sobre a inconveniência do mesmo no caso considerado:

a) ao pedido de uma das partes, a autoridade de nomeação transmitirá às duas partes, uma lista idêntica contendo pelo menos três nomes;

b) nos quinze dias subseqüentes à recepção de tal lista, cada parte poderá devolvê-la à autoridade de nomeação, após haver riscado os nomes sobre os quais tem objeção e numerado os nomes restantes na ordem de sua preferência;

c) na expiração do prazo àcima mencionado, a autoridade de nomeação nomeará o árbitro único entre as pessoas cujo nome figure nas listas a ela enviadas, seguindo a preferência indicada pelas partes;

d) se, por uma razão qualquer, a nomeação não possa ser feita segundo tal procedimento, a nomeação do árbitro único é deixada à apreciação da autoridade de nomeação.

4.A autoridade procederá à nomeação, levando em conta considerações próprias para garantir a nomeação de um árbitro independente e imparcial e considerando, igualmente, que pode ser desejável a nomeação de um árbitro de nacionalidade distinta daquela das partes.

Art. 79

1. Se três árbitros devem ser nomeados, cada parte indicará um deles. Ambos os árbitros assim nomeados, escolherão um terceiro, que desempenhará as funções de árbitro-presidente do tribunal.

2. Se, nos trinta dias da recepção da notificação do nome do árbitro designado por uma parte, a outra parte não lhe notificar o nome do árbitro de sua escolha:

a) a primeira parte pode pedir à autoridade de nomeação anteriormente designada pelas parrtes, de nomear o segundo árbitro; ou

b) se nenhuma autoridade de nomeação foi anteriormente designada pelas partes, ou se a autoridade de nomeação anteriormente designada se recusa a agir ou a nomear os árbitros, nos trinta dias da recepção do pedido de uma das partes em tal sentido, a primeira parte poderá solicitar ao Secretário Geral da Corte Permanente de Arbitragem da Haia designar a autoridade de nomeação. A primeira parte poderá, então, solicitar à autoridade de nomeação assim desig- 
nada, nomear o segundo árbitro. Num ou noutro caso, a nomeação do árbitro é deixada à apreciação da autoridade de nomeação.

3. Se nos trinta dias da nomeação do segundo árbitro, as duas partes não se tiverem colocado de acordo sobre a escolha do árbitro-presidente, este último será nomeado pela autoridade de nomeação, conforme o procedimento previsto no art., 6ㅇ para a nomeação do árbitro único.

Art. 80

1. Quando se pede a uma autoridade de nomeação indicar um árbitro conforme os arts. 6\% ou 7\%, a parte que faz o pedido, deve encaminhar-lhe uma cópia da notificação de arbitragem, uma cópia do contrato do qual se originou o litígio, ou ao qual se refere, e uma cópia da convenção de arbitragem, se esta não figurar no contrato. A autoridade de nomeação poderá pedir a uma ou ambas as partes informações que estima ter necessidade, para cumprir suas funções.

2. Quando a candidatura de uma ou de várias pessoas é proposta para a nomeação na qualidade de árbitro, os nomes de endereços completos dos interessados, bem como de sua nacionalidade, deverão ser indicados, acompanhados de uma descrição de seus títulos.

\section{RECUSA DE ÁRBITROS (ART. 9 A 12)}

Art. 99

Qualquer árbitro cuja nomeação se pretenda, deverá assinalar àqueles que o sondem, aquelas circunstâncias que sejam de natureza a levantar dúvidas sobre sua imparcialidade ou sua independência. Uma vez nomeado ou escolhido, o árbitro deverá assinalar às partes as mencionadas circunstâncias, se não o tiver já feito.

Art. 10

1. Qualquer árbitro pode ser recusado, se existirem circunstâncias que sejam de natureza a levantar sérias dúvidas sobre sua imparcialidade ou sua independência.

2. Uma parte não pode recusar um árbitro por ela designado, a não ser por uma causa cujo conhecimento teve, após aquela designação.

Art. 11

1. A parte que desejar recusar um árbitro, deve notificar sobre sua decisāo, nos quinze dias subseqüentes à data da notificação da nomeação de tal árbitro, 
ou nos quinze dias seguintes à data na qual tomou conhecimento das circunstâncias mencionadas nos arts. $9^{\circ} \mathrm{e} 10$.

2. A recusa deverá ser notificada à outra parte, ao árbitro recusado e aos membros do tribunal arbitral. A notificação deve ser feita por escrito e motivada.

3. Sendo um árbitro recusado por uma parte, a outra pode aceitar a recusa. $\mathrm{O}$ árbitro recusado pode, igualmente, afastar-se. Tal recusa ou afastamento não implicam no reconhecimento dos motivos da recusa. Em ambos os casos, o procedimento previsto nos arts. $6^{\circ}$ e $7^{\circ}$ se aplicam para a nomeação do substituto, mesmo que uma das partes não tenha exercido seu direito de nomear ou de participar na nomeação do árbitro recusado.

Art. 12

1. Se a recusa não for aceita pela outra parte, ou se o árbitro recusado não se afastar, a decisão relativa à recusa será tomada:

a) se a nomeação inicial foi deita por uma autoridade de nomeação - por esta autoridade;

b) se a nomeação inicial não foi feita por uma autoridade de nomeação, mas por autoridade designada anteriormente, - por esta autoridade;

c) nos outros casos, pela autoridade de nomeação que deverá ser designada conforme ao procedimento de designação de uma autoridade de nomeação previsto no art. 6․

2. Se a autoridade de nomeação admitir a recusa, um substituto é nomeado ou escolhido segundo o procedimento aplicável à nomeação ou à escolha de árbitros, previsto nos arts. 6 a 9; contudo, no caso de tal procedimento envolver a designação de uma autoridade de nomeação, a nomeação do árbitro será feita pela autoridade de nomeação que se pronunciou sobre a recusa.

\section{SUBSTITUIÇĀO DE UM ÁRBITRO}

Art. 13

1. Em caso de morte ou de renúncia de um árbitro durante o procedimento arbitral, um substituto será nomeado ou escolhido, segundo o procedimento previsto nos arts. 6ㅇ a 90, que for aplicável no caso de nomeação ou de escolha de árbitro que deve ser substituído.

2. Em caso de carência ou de impossibilidade de fato ou de direito de um ár- 
bitro exercer sua missão, aplicar-se-á o procedimento relativo à recusa ou substituição de árbitros previsto nos artigos anteriores.

\section{REPETIÇĀO ORAL EM CASO DE SUBSTITUIÇÃO DE UM ÁRBITRO} Art. 14

Em caso de substituição de um árbitro únicó ou do árbitro-presidente, em virtude dos arts. 11 a 13 , o procedimento oral que foi seguido antes da substituição, deverá ser repetido; no caso de substituição de outro árbitro, a decisão sobre repetir o procedimento é deixada à apreciação do tribunal arbitral.

\section{SEÇÃO III - PROCEDIMENTO ARBITRAL DISPOSIÇŌES GERAIS}

Art. 15

1. Sob reserva das disposições deste Regulamento, o tribunal arbitral pode proceder à arbitragem como julgar apropriado, na condição de serem as partes tratadas em pé de igualdade e de que, em qualquer estágio do procedimento, cada parte tenha a possibilidade de fazer valer seus direitos e de propor seus meios.

2. A pedido de uma das partes, ou em qualquer estágio do procedimento, o tribunal poderá organizar um procedimento oral para a produção de provas por testemunhas, inclusive peritos, ou para a apresentação oral de argumentos. Se nenhum pedido for formulado em tal sentido, o tribunal arbitral decidirá sobre a conveniência de organizar-se aquele procedimento, ou se o mesmo se desenvolverá só por documentos escritos.

3. Todos os documentos e informações que uma das partes fornecer ao tribunal arbitral, deverão ser comunicados, ao mesmo tempo, por ela à outra parte.

\section{LUGAR DA ARBITRAGEM}

Art. 16

1. Na falta de acordo entre as partes sobre o lugar da arbitragem, este será determinado pelo tribunal arbitral, considerando-se as circunstâncias da arbitragem.

2. O tribunal arbitral poderá fixar a localização da arbitragem no interior do país escolhido pelas partes. Poderá ouvir testemunhas ou realizar reuniōes de consultas, em qualquer lugar que lhe convier, considerando-se as circunstâncias da arbitragem. 
3. O tribunal arbitral poderá reunir-se em qualquer lugar que julgar apropriado para fins de inspeção de mercadorias ou de outros bens e para o exame de documentos. As partes deverão ser disto informadas com tempo suficiente, para ter a possibilidde de estarem presentes naqueles lugares.

4. A sentença será prolatada no lugar da arbitragem.

\section{LÍNGUA}

Art. 17

1. Salvo acordo das partes, o tribunal fixará, sem demora, logo após sua nomeação, a língua ou as línguas do procedimento. Esta decisão se aplicará ao pedido, à resposta e a qualquer outra manifestação por escrito e, no caso de procedmentos orais, à língua ou às línguas que forem utilizadas em tal procedimento.

2. O tribunal arbitral poderá ordenar que todos os documentos anexos ao pedido ou à resposta, e todos os documentos produzidos no curso do procedimento, que forem entregues na sua língua original, sejam acompanhados de uma tradução da língua ou nas línguas escolhidas pelas partes ou fixadas pelo tribunal arbitral.

\section{O PEDIDO}

Art. 18

1. Se o pedido não estiver exposto na notificação de arbitragem, o requerente deverá enviar, no prazo para tal fixado pelo tribunal arbitral, o pedido escrito ao requerido e a cada árbitro. Uma cópia do contrato e da convenção de arbitragem, se esta não figurar no contrato, deverá ser anexada ao pedido.

2. O pedido deverá conter as seguintes indicações:

a) nome e endereço das partes;

b) uma exposição dos fatos, em apoio do pedido;

c) os pontos litigiosos;

d) o objeto do pedido.

O requerente poderá juntar ao seu pedido todos os documentos que julgar pertinentes ou nela mencionar os documentos ou outros meios de prova que produzirá. 


\section{A RESPOSTA}

Art. 19

1. No prazo para tal fixado pelo tribunal arbitral, o requerido deverá endereçar sua resposta escrita ao requerente e a cada árbitro.

2. O requerido responderá às alíneas $b$, c e d do pedido (art. $18 \S 2$ ). Poderá juntar à sua resposta os documentos sobre os quais apóia sua defesa ou nela mencionar os documentos ou outros meios de prova que produzirá.

3. Na sua resposta, ou em estágio ulterior do procedimento arbitral, se o tribunal decidir que tal prazo é justificável pelas circunstâncias, o requerido poderá formar um pedido convencional fundado sobre o mesmo contrato, ou invocar um direito fundado sobre o mesmo contrato, como meio de compensação.

4. As disposições do $\S 2^{\circ}$ do art. 18 se aplicam ao pedido reconvencional e ao direito invocado como meio de compensação.

\section{MODIFICAÇÕES DO PEDIDO OU DA RESPOSTA}

Art. 20

No curso do procedimento arbitral, qualquer das partes pode modificar ou completar seu pedido ou sua resposta, a menos que o tribunal arbitral considere não dever autorizar a referida emenda, em razão do atraso com que é formulada, do prejuízo que acarretará à outra parte ou de qualqur outra circunstância. Contudo, um pedido não pode ser emendado, a ponto de sair fora do quadro da cláusula compromissória ou da convenção separada de arbitragem.

\section{DECLINATÓRIA DE COMPETÊNCIA ARBITRAL}

Art. 21

1. O tribunal arbitral pode pronunciar-se sobre as exceções levantadas sobre sua incompetência, inclusive qualquer exceção relativa à existência ou validade da cláusula compromissória ou da convenção separada de arbitragem.

2. O tribunal arbitral tem competência para pronunciar-se sobre a existência ou validade do contrato do qual a cláusula compromissória faça parte. Para os fins do art. 21, uma cláusula compromissória que faça parte de um contrato e que preveja uma arbitragem em virtude do presente Regulamento, será considerada como uma convenção separada das outras cláusulas do contrato. A constatação da nulidade do contrato pelo tribunal arbitral não causa, de pleno direito, a nulidade da cláusula compromissória. 
3. A exceção de incompetência deve ser apresentada no mais tardar, no depósito da resposta, ou em caso de pedido reconvencional, da réplica.

4. De maneira geral, o tribunal arbitral se pronunciará sobre a exceção de incompetência, tratando-a como uma questão preliminar. Poderá, contudo, prosseguir com a arbitragem e pronunciar-se sobre tal exceção, na sentença definitiva.

\section{OUTROS DOCUMENTOS ESCRITOS}

Art. 22

O tribunal decidirá quais são, além do pedido e da resposta, os outros documentos escritos que as partes devam ou possam lhe apresentar; fixará ele o prazo dentro do qual tais peças devam ser comunicadas.

\section{PRAZOS}

Art. 23

Os prazos fixados pelo tribunal arbitral para as comunicações escritas (inclusive o pedido e a resposta) não devem ultrapassar quarenta e cinco dias. Contudo, tais prazos podem ser prorrogados pelo tribunal arbitral, se este julgar que tal prorrogação é motivada.

\section{PROVAS E AUDIÊNCIAS (ART. 24 e 25)}

Art. 24

1. Cada parte deverá fornecer a prova dos fatos sobre os quais fundamenta seu pedido ou sua resposta.

2. Se julgar necessário, o tribunal poderá pedir a uma parte de lhe fornecer, bem como à outra, no prazo que fixar, um resumo dos documentos e outras provas que a parte interessada tem intenção de produzir, em apoio dos fatos que constituem o objeto do litígio e que se encontram expostos no pedido ou na resposta.

3. Em qualquer momento do procedimento, o tribunal arbitral poderá solicitar às partes produzirem provas complementares, fixando-lhes um prazo para tais efeitos.

Art. 25

1. Em caso de procedimento oral, o tribunal arbitral deverá notificar as partes com suficiente adiantamento, sobre a data, a hora e o local do procedimento. 
2. Se testemunhas devem ser ouvidas, cada parte comunicará, quinze dias antes da audiência, ao tribunal arbitral e à outra parte, os nomes e endereços das testemunhas que propōe serem ouvidas, precisando o objeto dos depoimentos e a língua na qual serão apresentados.

3. O tribunal arbitral tomará as providências para assegurar a tradução das exposiçōes orais feitas em audiência e para estabelecer uma redução a termo da audiência, se julgar que qualquer das medidas se impōe, em função das circunstâncias na espécie ou se as partes convencionaram a respeito e notificaram o tribunal arbitral de tal acordo, quinze dias, pelo menos, antes da audiência.

4. A audiência deverá desenrolar-se a portas fechadas, salvo convenção contrária das partes. O tribunal arbitral poderá pedir a testemunhas que se ausentem surante o depoimento de outras testemunhas. Ele é livre para fixar a maneira como as testemunhas serāo interrogadas.

5. A prova testemunhal pode igualmente ser administrada na forma de declarações escritas assinadas por testemunhas.

6. O tribunal arbitral é juiz da receptibilidade, da pertinência e da importância das provas apresentadas.

\section{MEDIDAS PROVISIONAIS OU CONSERVATÓRIAS}

Art. 26

1. A pedido de qualquer das partes, o tribunal arbitral poderá tomar quaisquer medidas provisionais que julgue necessárias no que concerne ao objeto do litígio, notadamente medidas conservatórias em relação a mercadorias litigiosas, prescrevendo, por exemplo, seu depósito em mãos de terceiros ou a venda de produtos perecíveis.

2. Tais medidas provisionais podem ser tomadas sob forma de sentença provisória. O Tribunal arbitral poderá exigir uma caução em títulos, em relação a custos ocasionados por tais medidas.

3. Um pedido de medidas provisionais dirigido por qualquer das partes a uma autoridade judiciária, não será considerada como incompatível com a convenção de arbitragem, nem como uma renúncia ao direito de fazer valer a citada convenção.

\section{PERITOS}

Art. 27

1. O tribunal arbitral poderá nomear um ou vários peritos encarregados de lhe apresentar, por escrito, relatórios sobre pontos precisos que ele determinar. 
Uma cópia do mandato do perito, tal qual fixado pelo tribunal arbitral, será comunicada às partes.

2. As partes deverão fornecer ao perito todas as informações apropriadas ou deverão submeter à sua inspeção quaisquer documentos ou coisas pertinentes, que aquele possa solicitar-lhes. Qualquer disputa que surja entre uma das partes e o perito sobre o fundamento do pedido, será submetido ao tribunal arbitral, que a resolverá.

3. Recebido o relatório do perito, o tribunal arbitral enviará uma sua cópia às partes, que terão a possibilidade de formular por escrito sua opinião a respeito. As partes terão o direito de examinar qualquer documento invocado pelo perito em seus relatórios.

4. A pedido de qualquer das partes, o perito, após a entrega de seu relatório, poderá ser ouvido em audiência, à qual as partes poderão estar presentes e interrogá-lo. Nesta audiência, qualquer das partes poderá fazer vir na qualidade de testemunhas, peritos que deporão sobre as questões litigiosas. As disposições do art. 25 são aplicáveis a tais procedimentos.

\section{REVELIA}

Art. 28

1. Se no prazo fixado pelo tribunal arbitral, o requerente não apresentar seu pedido ou não puder invocar um impedimento legítimo, o tribunal arbitral ordenará o encerramento ${ }^{(7)}$ do procedimento arbitral. Se, no prazo fixado pelo tribunal arbitral, o requerido não apresentar sua resposta, sem invocar um impedimento legítimo, o tribunal arbitral ordenará o prosseguimento do procedimento.

2. Se uma das partes, regularmente convocada conforme o presente Regulamento, não comparecer à audiência, sem invocar um impedimento legítimo, o tribunal arbitral poderá prosseguir com a arbitragem.

3. Se uma das partes, regularmente convidada a produzir documentos, não os apresentar nos prazos fixados, sem invocar um impedimento legítimo, o tribunal arbitral poderá decidir na base dos elementos de prova dos quais disponha.

(7) “... ordonne la clôture de la procédure arbitrale". Preferimos traduzir por "encerramento" e não por "extinção", dada a conotação técnica deste conceito no D. Processual Civil brasileiro (Nota do tradutor). 


\section{ENCERRAMENTO DOS DEBATES}

Art. 29

1. O tribunal arbitral poderá solicitar às partes se têm ainda provas a apresentar, testemunhos a serem produzidos ou declarações a serem feitas, e, na ausência de tais elementos, declarará encerrados os debates.

2. O tribunal arbitral poderá, se estimar necessário em razão de circunstâncias excepcionais, decidir por iniciativa própria ou a pedido de uma das partes, a reabertura dos debates, em qualquer momento antes da prolação da sentença.

\section{RENÚNCIA AO DIREITO DE FAZER VALER O PRESENTE REGULAMENTO}

Art. 30

Qualquer parte que, sabendo que uma das disposiçōes ou uma das condições enunciadas no presente Regulamento, não foi respeitada, e mesmo assim deixar prosseguir a arbitragem sem formular objeções, é reputada como tendo renunciado a seu direito de apresentar objeção.

\section{SEÇÃO IV - A SENTENÇA DECISŌES}

Art. 31

1. Sendo o tribunal em número de três, qualquer sentença ou outra decisão do tribunal arbitral, será proferida por maioria.

2. No que diz respeito a questões de procedimento, na falta de maioria ou se o tribunal arbitral o autorizar, o árbitro-presidente poderá decidir por ele mesmo, sob reserva de eventual revisão do tribunal arbitral.

\section{FORMA E EFEITO DA SENTENÇA}

Art. 32

1. O tribunal arbitral poderá pronunciar nāo só sentenças definitivas, mas igualmente sentenças provisórias ou parciais.

2. A sentença é dada por escrito. Ela não é susceptível de apelação perante instância arbitral. As partes se comprometem a executar, sem demora, a sentença.

3. O tribunal deverá motivar sua sentença, a menos que as partes tenham convencionado que tal não deva ser. 
4. A sentença deverá ser assinada pelos árbitros e fazer menção à data e ao lugar onde ela foi prolatada. Sendo os árbitros em número de três e faltando a assinatura de um deles, o motivo da ausência de assinatura será mencionado na sentença.

5. A sentença não poderá ser publicada, senão com o consentimento de ambas as partes.

6. Cópias da sentença assinadas pelos árbitros serão fornecidas pelo tribunal arbitral às partes.

7. Se a lei em matéria de arbitragem do país no qual a sentença for prolatada, impuser ao tribunal arbitral a obrigação de depositar a sentença ou de fazê-la registrar, o tribunal satisfará esta obrigação no prazo prvisto pela lei.

\section{LEI APLICÁVEL, “AMIABLE COMPOSITEUR”(8)}

Art. 33

1. O tribunal arbitral aplicará a lei designada pelas partes, como sendo a lei aplicável ao mérito do litígio ("fond du litige"). Na falta de tal indicação pelas partes, o tribunal arbitral aplicará a lei designada pela norma de conflito de leis que julgar aplicável na espécie.

2. O tribunal arbitral só decidirá na qualidade de "amiable compositeur" (ex aequo et bono) se o tribunal arbitral for para tal, expressamente autorizado pelas partes, e se este tipo de arbitragem for permitido pela lei aplicável ao procedimento arbitral.

3. Em qualquer caso, o tribunal arbitral decidirá conforme as estipulações do contrato e levará em consideração os usos do comércio aplicáveis ao negócio ("des usages du commerce applicables à la transaction").

\section{TRANSAÇÃO OU OUTROS MEIOS DE ENCERRAMENTO DO PRO- CEDIMENTO}

Art. 34

1. Se antes de a sentença ser proferida, as partes convierem em uma transação que resolva o litígio, o tribunal arbitral emitirá um declaração de encerra-

(8) $O \S 2^{\circ}$ do art. 33 define os limites da atuação do “amiable compositeur", intraduzível "à la lettre" em português. No direito brasileiro, a tradução mais aproximada seria: julgador por eqüidade (árbitros autorizados pelas partes a "julgarem por eqüidade, fora das regras e formas de direito", art. 1075, IV do CPC:) (Nota do tradutor). 
mento do procedimento arbitral, ou se ambas as partes lhe solicitarem, constará o feito por uma sentença arbitral homologatória de acordo das partes ${ }^{(9)}$. Esta sentença não necessita ser motivada.

2. Se antes de a sentença ser proferida, tornar-se inútil ou impossível, por qualquer razão não mencionada no $\S 1 \%$, prosseguir-se com o procedimento arbitral, o tribunal arbitral informará às partes de sua intenção de emitir uma declaração de encerramento do procedimento. $O$ tribunal arbitral está autorizado a emitir tal declaração, a menos que uma ds partes levante objeções fundamentadas.

3. O tribunal arbitral deverá remeter às partes uma cópia da declaração de encerramento do procedimento arbitral ou de uma sentença homologatória de acordo das partes, devidamente assinada pelos árbitros. As disposiçōes dos §§ $2^{\circ}$ a 7 o do art. 32 serão aplicáveis às sentenças arbitrais homologatórias de acordo das partes.

\section{INTERPRETAÇĀO DA SENTENÇA}

Art. 35

1. Nos trinta dias da recepção da sentença, qualquer das partes poderá, mediante notificação à outra, solicitar ao tribunal arbitral de dar-lhe uma interpretação.

2. A interpretação será dada por escrito, nos quanrenta e cinco dias de recepção do pedido. A interpretação fará parte integrante da sentença e as disposiçōes dos $\$ \S 2^{\circ}$ a $7^{\circ}$ do art. 32 lhe serão aplicáveis.

\section{RETIFICAÇÃO DA SENTENÇA}

Art. 36

1. Nos trinta dias da recepção da sentença, qualquer das partes poderá, mediante notificação à outra, solicitar ao tribunal arbitral retificar no texto da sentença, qualquer erro de cálculo, qualquer erro material ou tipográfico ou qualquer erro de idêntica natureza. O tribunal arbitral poderá, nos trinta dias da comunicação da sentença às partes, fazer tais retificaçōes por iniciativa própria.

2. As retificações serão feitas por escrito e as disposições dos $\S \S 2^{\circ}$ a $7^{\circ}$ do art. 32 lhe são aplicáveis.

(9) "Sentence arbitrale rendue d'accord partie" - em que pese a inaplicabilidde do conceito de "homologação" no procedimento arbitral, dado seu caráter eminentemente voluntário, a tradução constante no texto foi a única possível a respeitar a "mens legis". 


\section{SENTENÇA ADICIONAL}

Art. 37

1. Nos trinta dias da recepção da sentença, qualquer das partes poderá, mediante notificação à outra, solicitar ao tribunal arbitral prolatar sentença adicional sobre qualquer ponto do pedido exposto no curso do procedimento de arbitragem, mas omisso na sentença.

2. Se o tribunal arbitral julgar o pedido justificado e estimar que a omissão pode ser retificada sem necessitar novas audiências ou novas provas, completará sua sentença, nos sessenta dias que se seguirem à recepção do pedido.

3. As disposições dos $\$ \S 2^{\circ}$ a $7^{\circ}$ do art. 32 são aplicáveis à sentença adicional.

\section{CUSTAS (ART. 38 a 40)}

Art. 38

O tribunal arbitral fixará as custas da arbitragem na sentença. As "custas'"(10) compreendem unicamente:

a) os honorários dos membros do tribunal arbitral, indicados separadamente para cada árbitro e fixados pelo próprio tribunal, segundo o art. 39;

b) as despesas ${ }^{(11)}$ de deslocamento e outras despesas feias pelos árbitros;

c) as despesas causadas por qualquer peritagem ou por qualquer outra ajuda solicitada pelo tribunal arbitral;

d) as despesas com o deslocamento e outras indenizações de testemunhas, na medida em que tais despesas foram aprovadas pelo tribunal arbitral;

(10) No original em francês, "frais", entre aspas. Tanto em francês como em português, "frais" e "custas" podem ter uma acepção vulgar de despesa, custo, quanto uma acepçāo jurídica (sobretudo custas, fem. pluralia tantum) de "despesas feitas em processo judicial"; (Dic. Aurélio, verbete: custa e Dictionnaire Français-Portugais Liv. Bertrand, Dicionário Bertrand, Paris, 1978, verbete: "frais" (Nota do tradutor).

(11) No original em francês frais sem aspas; traduziremos por despesas (Nota do tradutor). 
e) as despesas em matéria de representação ou de assistência jurídica realizadas pela parte vencedora, e tais despesas constituírem um dos pontos do pedido de arbitragem e na medida em que o tribunal arbitral julgue seu montante razoável;

f) se for o caso, os honorários e despesas das autoridades de nomeação, bem como as despesas do Secretário Geral da Corte Permanente de Arbitragem da Haia.

Art. 39

1. O montante dos honorários dos membros do tribunal arbitral deve ser razoável, levando-se em consideração o valor em litígio, a complexidade do assunto, o tempo que os árbitros lhe consagraram e quaisquer outras circunstâncias pertinentes ao caso.

2. Se a autoridade de nomeação foi escolhida pelas partes de comum acordo ou se designada pelo Secretário Geral da Corte Permanente de Arbitragem da Haia, e, tendo aquela autoridade publicado tabela pelos honorários dos árbitros nomeados em litígios internacionais que ela administra, o tribunal arbitral fixará o montante de seus honorários, levando em consideração tal tabela, na medida em que julgue apropriado às circunstâncias na espécie.

3. Se a autoridade de nomeação não tiver publicado tabela para honorários dos árbitros nomeados nos litígios internacionais, cada parte poderá, a qualquer momento, solicitar à autoridade de nomeação estabelecer uma nota em que indique a base de cálculo de honorários, que é habitualmente aplicada nos litígios internacionais nos quais a autoridade nomeia árbitros. Se a autoridade de nomeação aceitar estabelecer a referida nota, o tribunal arbitral fixará o montante de seus honorários levando em consideração as informações assim fornecidas, na medida em que julgue apropriado às circunstâncias da espécie.

4. Nos casos contemplados nas alíneas 2 e 3, tendo, a pedido de uma das partes, a autoridade de nomeação aceitado aquele mister, o tribunal arbitral somente fixará o montante de seus honorários, após ter consultado a autoridade de nomeação, que poderá dirigir ao tribunal arbitral, qualquer observação que julgue apropriado no concernente a seus honorários.

Art. 40

1. Salvo disposto no $\S 2$, as custas da arbitragem ficarão a cargo, em princípio, da parte sucumbente. Todavia, poderá o tribunal arbitral reparti-las entre as partes, na medida em que julgue apropriado às circunstâncias em espécie. 
2. No que concerne às despesas em matéria de representação ou de assistência jurídica, conforme a alínea $€$ do art. 38, o tribunal arbitral poderá, tendo em vista as circunstâncias em espécie, determinar a parte sobre cujo encargo serão colocadas tais despesas, ou reparti-las entre as pates, na medida em que julgue apropriado.

3. Quando o tribunal arbitral pronunciar uma declaração de encerramento do procedimento arbitral ou uma sentença homologatória de acordo das partes, (sentence d'accord partie), fixará as custas da arbitragem conforme os art. $38 \mathrm{e}$ $\S 1^{\circ}$ do art. 38, no texto da declaração ou daquela sentença.

4. O tribunal arbitral não poderá perceber honorários suplementares por interpretar ou retificar sua sentença ou por prolatar uma sentença adicional conforme os arts. 35 a 37.

\section{CONSIGNAÇÃO DO MONTANTE DAS CUSTAS}

Art. 41

1. Desde sua constituição, o tribunal arbitral poderá solicitar a cada parte consignar soma idêntica, a título de adiantamento sobre as custas mencionadas no art. 38 incisos a, b e c.

2. No curso do procedimento arbitral, o tribunal arbitral poderá solicitar às partes consignar somas suplementares.

3. Se uma autoridade de nomeação for escolhida pelas partes de comum acordo, ou designada pelo Secretário Geral da Corte Permanente de Arbitragem da Haia, e, se a pedido de uma das partes a autoridade de nomeação aceitar este mister, o tribunal arbitral somente fixará o montante das somas ou das somas suplementares a consignar, após ter consultado a autoridade de nomeação, que poderá dirigir ao tribunal arbitral quaisquer observações que julgar apropriadas, no concernente ao montante de tais consignaçōes.

4. Se as somas cuja consignação é pedida, não forem integralmente depositadas nos trinta dias da recepção do pedido, o tribunal arbitral disso informará as partes, a fim de que um ou outra dente elas, possa efetuar o depósito solicitado. Se tal depósito não for efetuado, o tribunal poderá ordenar a suspensão ou o encerramento do procedimento arbitral.

5. Após a prolação da sentença, o tribunal arbitral prestará contas às partes, da utilização das somas recebidas em depósito e lhes restituirá qualquer saldo não despendido. 


\section{ANEXO - II \\ PARECER}

\section{Projeto de Conveção sobre Arbitragem Comercial Internacional - (Lei- Modelo da UNCITRAL)}

São Paulo, Arcadas, em 09 de novembro de 1984

Encaminha Sua Excelência o Senhor Embaixador Prof. Dr. Miguel Franchini-Netto, DD. Representante Permanente do Brasil junto à Comissão das Nações Unidas para o Direito do Comércio Internacional, UNCITRAL, um PROJETO DE CONVENÇĀO SOBRE LEI-MODELO DE ARBITRAGEM COMERCIAL INTERNACIONAL, oriundo daquela Comissão da ONU, com o pedido de minha apreciação do mesmo, tendo em vista a legislação interna e $o$ interesse nacional.

\section{I - O PROJETO DA UNCITRAL,A/CN.9/WG.2/7/CRP.2/ADD.10 de 19/II/1984}

1. Trata-se de um projeto de texto de uma lei modelo sobre arbitragem comercial internacional, aplicável nas relações entre particulares, submetidos a legislações estatais distintas, segundo a definição do art. 1으, § 2\%. Excluem-se, portanto, as arbitragens que envolvem relações entre Estados ou entre Estados e organismos internacionais, regidas pelas normas do Direito Internacional Público, bem como as arbitragens sobre investimentos internacionais, regidas pela Convenção BIRD de 1965, "Convenção sobre Resolução de Controvérsias Relativas a Inversōes entre Estados e Particulares", a qual criou o Centro Internacional para Solução de Disputas sobre Inversões, e da qual, nenhum Estado latino-americano significativo é parte.

2. $\mathrm{O}$ assunto se acha na atualidade regido pelas seguintes convençōes internacionais: a) de âmbito regional, a Convenção Européia sobre a Arbitragem Comercial Internacional assinada em Genebra em 21 de aberil de 1961 e a Convenção Interamericana sobre Arbitragem Comercial Internacional, assinada no Panamá em 30 de janeiro de 1975; b) de âmbito universal, o Protocolo de Genebra de 1923, relativo às cláusulas de arbitragem, vigente no Brasil (Decreto $\mathrm{n}$ - 21.167 de 22 de maio de 1932), a Convenção de Genebra de 1927, para a execução das Sentenças Arbitrais Estrangeiras e, finalmente, a Convenção para o Reconhecimento e a Execução de Sentenças Arbitrais Estrangeiras, assinada em Nova York em 10 de junho de 1958, que no seu art. VII, § 2, abroga as anteriores, na medida em que os Estados passem a fazer parte da mesma.

3. Assim sendo, no Brasil e para o Brasil, está vigente tão somente o Protocolo de Genebra de 1923, ou em outras palavras, aqueles princípios jurídicos que são comuns ao Protocolo de Genebra de 1923 e a Convenção de Nova 
York de 1958. Tais esclarecimentos são necessários, uma vez que grande parte das arbitragens comerciais internacionais se verificam entre parceiros comerciais brasileiros e norte-americanos; ora, os EUA não são parte no Protocolo de Genebra de 1923, mas são partícipes da Convenção de Nova York de 1958, e o Brasil tão somente ratificou o mencionado Protocolo. Contudo, não é por inexistir um tratado entre Brasil e os EUA sobre a validade da cláusula compromissória que as arbitragens entre particulares submetidos ás mencionadas jurisdiçōes, deixaram de ser realizadas. Em vários pareceres, temos sustentado com sucesso, perante a Comissão de Arbitragem da Câmara de Comércio Internacional de Paris (que por motivos de sigilo, deixamos de fazer a exata referência), que nas arbitragens comerciais internacionais entre partes submetidas à legislação brasileira e de Nova York, cada qual, a cláusula compromissória tem validade, não porque exista um tratado entre ambos os Países, mas porque há princípios comuns vigentes em ambas as legislações: no Brasil, por força do Protocolo de Genebra de 1923, e nos EUA, por força da Convenção de N. York de 1958, naqueles trechos que repetem o mencionado Protocolo e, são vigentes, por força dos princípios gerais de direito comuns às legislações, apoiados pelo extraordinário vigor jurígeno dos usos e costumes no comércio internacional.

4. O Projeto da UNCITRAL pretende transformar-se em tratado internacional. Se o fôr, será um tratado do tipo LAW MAKING TREATY, ou seja, um acordo internacional regido pelo Direito Internacional Público, e que versa sobre normas de direito privado, implicando, assim, na imediata transformação da legislaçāo local, uma vez que disciplinará, diretamente, a conduta de pessoas de direito privado. Nesse aspecto, veja-se a relutância do sistema brasileiro de admitir tratados dessa espécie, como atesta o longo tempo em que o Supremo Tribunal Federal levou para reconhecer como lei interna as Convenções de Genebra sobre cambiais, promissórias e cheques. Na verdade, semelhantes convenções internacionais que dispõem sobre direito uniforme, encontram certa resistência por parte do Judiciário brasileiro, em que pese a doutrina considerar a supremacia do Direito Internacional sobre o direito interno.

5. Outro aspecto a considerar no Projeto da UNCITRAL é que ele se reveste de um detalhamento, aparentemente incompatível com um tratado interestatal, onde a técnica legislativa aconselha a edição de normas gerais, programáticas, deixando a implementação das mesmas para atos normativos de organismos intergovernamentais. No caso de arbitragens comerciais internacionais, onde impera o princípio da plena liberdade dos contratantes para estabelecer normas do procedimento do árbitro ou árbitros, um espírito de regular minúcias num texto normativo, em especial entre Estados, é altamente desaconselhável, por ferir os princípios da criatividade caracteristica nas arbitragens entre particulares. 
6. As regras do Projeto da UNCITRAL, conforme sua análise, melhor caberiam numa Comissão de Arbitragem, do que no quadro normativo dos Estados. $\mathrm{Na}$ verdade, com ligeiras modificaçōes, elas já se acham inseridas na Comissão Interamericana de Arbitragem Comercial, nascida da Convenção do Panamá de 1975: são as Regras de Procedimento da Comissão Interamericana de Arbitragem Comercial, conforme emendadas e em vigor a partir de $1^{\text {o }}$ de janeiro de 1978. Aquelas pequenas modificaçōes dizem respeito, em particular, a quem recorrer, na hipótese de uma das partes não cooperar na formação do tribunal, ou na indicação do árbitro único. Assim, nas Regras do IACAC, art. 60 $\S \S 10 \mathrm{e}$ $2^{\circ}$, não havendo acordo entre as partes quanto à indicação do árbitro único, sua escolha será feita pelo IACAC; no Projeto da UNCITRAL, art. 11 § $3^{\circ}$ (b) e art. 11, § 50, tal escolha é feita pelo tribunal judiciário nacional que teria competência para conhecer a questão. Igualmente, na indicação do segundo árbitro pela parte realcitrante, a escolha é do IACAC (art. $7^{\circ} \S 2^{\circ}$ das Regras) e no Projeto da UNCITRAL, pelo juiz togado (art. 11 \$§ 3 (a) e 59). Outra diferença reside nos motivos e procedimentos para a recusa dos árbitros (challenge of arbitrators): no art. 12 das Regras, a decisão sobre a recusa será tomada pelo IACAC, e no Projeto da UNCITRAL, pelo tribunal judiciário (arts. 12 e 13 \& 3-, inclusive mais detalhados no procedimento a ser seguido). No Projeto da UNCITRAL nada há sobre custas e depósito, que, nas Regras do IACAC, constam dos arts. 39 e 40. Enfim, nas Regras do IACAC há uma cláusula compromissória recomendada (no início das Regras, sem numeração articular), ao passo que no Projeto da UNCITRAL, no art. $7^{\circ}$, não se indica o modelo da cláusula, mas tão somente sua definição e forma do acordo de arbitragem.

7. Entre o sistema detalhista proposto pela UNCITRAL e pelo IACAC, de um lado, e o sistema de regras gerais da Convenção de Nova York de 1958, pode-se ter um sistema intermediário, como o da Convenção Européia sobre Arbitragem Comercial Internacional, que se reveste de melhor técnica.

8. Por se tratar de um projeto de convenção sobre lei uniforme, acreditamos na quase impossibilidade de sua adoção. A convenção de Genebra, Européia, foi possível ser adotada no seu relativo detalhamento, por regular ela relações entre Estados de nível econômico semelhantes, inda que postados em regimes díspares, como os Estados do Leste Europeu, que, nem por adotarem o monopólio estatal do comércio exterior, deixam de, largamente, aplicar a arbitragem para as soluções de conflitos entre os "combinados" e as empresas ou os Estados capitalistas.

\section{I - O PROJETO DA UNCITRAL E A LEGISLAÇÃO E JURISPRU- DÊNCIA BRASILEIRAS}

9. A legislação brasileira, tanto o Código Civil quanto o Código de Processo Civil, não faz qualquer distinção entre arbitragens internas (ou seja, tipicamente 
brasileiras) e internacionais. Nas arbitragens internas, a legislação faz menção tão somente ao compromisso como condição de validade do laudo arbitral, sendo que a atribuição de mera obrigaçāo de fazer (pactum de contrahendo) à cláusula compromissória foi obra da jurisprudência judiciária. Assim sendo, é lei interna no Brasil,de que um laudo arbitral só é válido e pode ser homologado pelo poder judiciário para valer como título executivo judicial, se for antecedido de um compromisso, contrato formal, regulado naqueles diplomas normativos. De seu lado, o compromisso, se apresentado como preliminar na contestação do réu, (CPC art. 301-IX e seu § 4'), tem o condão de causar a extinção do processo, sem julgamento do mérito (CPC art. 267-VII). Quanto à cláusula compromissória, tem um simples valor de obrigação de fazer (de louvar-se em árbitros) e sua inadimplência, que se constitui no recurso ao Judiciário, só pode dar lugar á aplicação de penas contratuais (se elas previrem multas para o descumprimento da cláusula), à inadimplência de todo contrato (na condição de haver provisões para tal) ou ainda, como qualquer obrigação de fazer descumprida, a pedido de indenizaçōes por perdas e danos. Inexiste antecedente jurisprudencial que mostre o recurso ao Judiciário para forçar uma parte a cumprir a cláusula compromissória (execução forçada, ou como se acha em moda dizer, execução específica).

10. No que dis respeito às arbitragens estrangeiras, cuja execução se tem pedido no Brasil, é necessário descrever a evolução da jurisprudência do Supremo Tribunal Federal, no que se reere à validade da cláusula compromissória no Brasil. Até a presente data, nenhum julgado se pronunciou sobre a existência ou aplicabilidade do Protocolo de Genebra de 1923 no Brasil, evidentemente por falta de o assunto ter sido trazido a exame do Pretório Escelso. Na verdade, tal fato prova a afirmação anterior que fizemos da relutância de os tribunais superiores brasileiros aplicarem tratados internacionais como leis internas no Brasil.

11. Apoiados no falso entendimento de que o juízo competente para homologar laudos arbitrais estrangeiros no Brasil, para o fim de dar-lhes execução compulsória, os advogados brasileiros encaminhavam laudos arbitrais, diretamente ao Supremo Tribunal Federal, numa evidente confusão com sentença judiciária estrangeira (esta sim, de competência originária do Presidente do S.T.F. para homologação). Ora, em todas as vezes que fci chamado a pronunciar-se, o STF declararia, com razão, que sua competência não se referia à homologação de laudos arbitrais estrangeiros, sem, no entanto, dar qualquer solução para o assunto da execução compulsória dos mesmos no Brasil.

12. A jurisprudência vinha numa linha coerente, até que no caso Northern vs. Kern, SE-1982 de 03 de junho de 1970, RTJ/54, o Supremo Tribunal Federal afirmou que no caso de vir o laudo arbitral estrangeiro homologado pela Justiça estrangeira ou por qualquer autoridade do país onde foi prolatado, ele, SFT, não hesitaria em homologar a sentença judiciária homologatória do laudo. Os casos se sucederam no STF e firmaram jurisprudência: se $Q$ laudo arbitral 
foi prolatado num país estrangeiro, se foi ali homologado pela Justiça local, ele, STF, homologaria a sentença judiciária, dando assim força executória a laudos arbitrais estrangeiros, mesmo que os mesmos se baseassem unicamente na cláusula compromissória, e mesmo que inexistisse compromisso. $\mathrm{O}$ fundamento de tal procedimento se baseia no fato de ser a sentença homologatória do STF um procedimento de natureza delibatória, onde a Justiça brasileira não pode modificar o conteúdo da sentença judiciária estrangeira. Em todas as ocasiōes, foram levantadas preliminares de ofensa á ordem pública brasileira, impeditivas da homologação da sentença estrangeira; o STF, contudo, desprezou aquelas preliminares, tendo, assim, fixado os precedentes de que a falta de compromisso num laudo estrangeiro homologado pela justiça estrangeira, não é fato impeditivo de sua homologação pelo STF, pois não ofende à ordem pública. Isto posto, o que a jurisprudência do STF acabou por fixar foi a plena validade da cláusula compromissória nas arbitragens estrangeiras e, se houver dúvidas quanto à validade da mesma, tal incidente deve ser discutido na justiça estrangeira que homologou o laudo arbitral e não perante o STF, que não poderá modificar o mérito do "decisum" pela Justiça estrangeira.

13. Segue-se uma lista dos acórdãos do STF em que se provam a distinção jurisprudencial entre arbitragens internas brasileiras e arbitragens internacionais, e nessas, a plena validade de cláusulas compromissórias, assim como os assuntos em que aparecem as preliminares de ordem pública brasileira, impedientes de adoção de normas estrangeiras: Northern vs. Kern, RTJ/54 (Se-1982 de 03 de junho de 1970); Otraco vs. Condil, RTJ/60 (SE-2.006 de 18 de novembro de 1971); Centrofin vs. La Pastina, RTJ/91 (SE-2.178 de 03 de junho de 1979) e RTJ/92 (Ag. Reg., 2.178 de 14 de novembro de 1979); Nouvelle vs. Caldas, RTJ/95 (Ag. Reg., 2.476 de 09 de abril de 1980); N.V. Bunge vs. Pacaembu, RTJ/95, bis (Ag. Reg., 2.671); Nam Fung vs. Soares de Oliveira, RTJ/103 (SE-2.597 de 22 de abril de 1982); Walter Matter vs. Fenelon (DJ de 02/12/1983); Palmer \& Wall vs. Algoper, RTJ/105 (SE-2.456 de 03 de março de 1983) Anderson Clayton vs. Irodrusa, RTJ/107 (SE-2.766 de 01 de julho de 1983).

14. O Supremo Tribunal Federal, nos casos mencionados, tem considerado normas de ordem pública, no que se refere a arbitragens comerciais internacionais os seguintes aspectos: a) no juízo de homologação do laudo arbitral perante a Justiça estrangeira, é necessário citação da parte brasileira (leia-se, domiciliada no Brasil), através de carta rogatória, não de atribuindo ao "affidavit" da "common law" nenhuma validade no Brasil; b) o laudo arbitral pode não ser motivado, mas a sentença judiciária de homologação do mesmo deve ser motivada; c) a sentença judiciária de homologação, se dada por tribunal judiciário, deve revestir-se da forma de sentença judiciária passada em julgado, e não meramente chancelada pelo tribunal (uso judiciário na Inglaterra e nos EUA, onde os advogados têm fé pública e, considerados quase-funcionários do 
Poder Judiciário, sua mera assinatura, perante o notariado dos tribunais the confere faculdades de documentos oriundos do Poder Judiciário, com toda sua força probante). Em resumo, o que se pode afirmar é que nos assuntos de arbitragens internacionais, o STF tem exigido os requisitos essenciais da lei brasileira, tão somente para a homologação das sentenças judiciárias homologatórias estrangeiras (pouco importando de como o laudo que elas homologam foi prolatado, uma vez que o STF não pode modificar o mérito do "decisum" do Judiciário estrangeiro).

15. Se o Projeto da UNCITRAL se tornar lei interna brasileira, dará a cláusula compromissória o mesmo efeito que na legislação doméstica se atribui ao compromisso: dar causa à extinção do processo, sem julgamento do mérito. Note-se, que por força do Protocolo de Genebra de 1923, a cláusula arbitral já deveria ter tais efeitos no Brasil, mas os tribunais não têm aplicado tais conseqüências da mesma, repita-se, pela relutância da jurisprudência brasileira em aplicar normas internacionais.

16. Sem dúvida, pelo entendimento dos efeitos da cláusula compromissória, unicamente nos seus efeitos de obrigação de fazer, portanto, com a denegação de seus efeitos negativos de causar a incompetência do Judiciário, se existe a via arbitral pactuada em contratos anteriores, faz da arbitragem comercial internacional um instituto pesado perante a lei brasileira, pois obriga as partes a recorrerem ao Judiciário estrangeiro (para a homologação do laudo ali passado) e novamente ao Judiciário brasileiro (para homologação da sentença homologatória estrangeira do laudo). Sabe-se que o recurso à arbitragem nos negócios transnacionais é uma das formas mais atraentes e compatíveis com sua realidade: o recurso à arbitragem, por vezes é a única forma de resolver litígios nos negócios, em especial quando se tem em mira um Judiciário cada vez menos aparelhado para estudar questōes complexas dos negócios internacionais entre pessoas de direito privado, ou mesmo, entre essas, estrangeiras, e pessoas, em princípio, portadoras de imunidades de jurisdição (leia-se: a miríade de situações em que órgãos da Administração descentralizada realizam negócios com particulares estrangeiros, sem perder seus privilégios de foros especiais, segundo a lei brasileira).

17. Na tentativa de tornar a arbitragem mais praticável no Brasil, inclusive pelo motivo urgente de desafogar o Judiciário, necessário mencionar duas realizações recentes e que refletem a busca de tornar a legislação brasileira mais coerente com as vantagens que o instituto oferece. Em primeiro lugar, há um Anteprojeto de reforma do Código de Processo Civil (Portaria no 319/81 do Ministro da Justiça, publicada in DOU de 27 de maio de 1981) em que, por sugestōes do Ministério Extraordinário para a Desburocratização, procurou-se dar mais agilidade à arbitragem, dando à cláusula arbitral seu papel de afastamento do Judiciário, quando presentes nos contratos sub judice e dando ao laudo arbitral a mesma força e validade que a sentença judiciária, afastando-se, assim, a 
necessidade de homologaçã̉o judicial do laudo arbitral. Em segundo lugar, no Projeto do Novo Código Civil (Projeto de Lei no 634-A de 1975, in Diário do Congresso Nacional de 14 de setembro de 1983, Suplemento) nos artigos 864 e 865 , pela primeira vez na legislação brasileira, há dispositivos legislativos sobre a cláusula compromissória, dando-lhe plena validade, no mesmo pé de igualdade que o compromisso, além de ambos, Anteprojeto e Projeto, estabelecerem mecanismos coercitivos para forçar as partes a submeterem-se ao procedimento arbitral acordado em contrato (mecanismos de indicação de árbitro único ou do árbitro ou do presidente do tribunal arbitral, no caso de falta de cooperação de uma das partes).

18. Enfim, é mister dizer que, mesmo com os esforços de tornar a arbitragem comercial particular mais praticada no Brasil, conforme se afirmou no parágrafo anterior, um fato digno de nota é a ausência na legislação brasileira de dois diplomas internacionais significativos e que deixam o Brasil completamente fora do movimento internacional de prestigiamento da solução arbitral: a Convenção de Nova York de 1958 e a Convenção BIRD de 1965 (e nessse particular último, é necessário que a Consultoria Jurídica do Ministério das Relações Exteriores reveja as razões pela não assinatura da Convenção BIRD, inclusive por motivos mais justificáveis do que aqueles constantes no Parecer de agosto de 1964, publicado in Boletim da Sociedade Brasileira de Direito Internacional, ano XX, no 39/40, dezembro de 1964, p. 265). Por outro lado, a assinatura e não ratificação da Conveção do Panamá de 1975, merecem estudos prioritários antes de se pensar em qualquer conseqüência, relativamente à adoção das regras sobre arbitragem, conforme aventadas pela UNCITRAL.

\section{CONCLUSÕES}

19. Pela extremada força que os usos e costumes exercem sobre as regras do comércio internacional realizado entre pessoas de direito privado, as Convenções de direito uniforme têm a função de facilitar os relacionamentos, por vezes, impondo-se às legislaçōes locais, mesmo que inexista um ato vinculativo entre os Estados; prova de tal afirmativa é o fato de, apesar da pouca importância, diríamos mesmo, nenhuma importância que o Judiciário brasileiro tem conferido ao Protocolo de Genebra de 1923 no Brasil, (o fato) é que as realidades do comércio internacional forçaram o reconhecimento dos efeitos da cláusula compromissória nas arbitragens privadas internacionais.

20. Por outro lado, a circunstância de ser o Brasil não parte da Convenção de Nova York de 1958, do BIRD de 1965 e do Panamá de 1975, o que atesta estar o País isolado de uma tendência universal de prestigiar as soluções arbitrais, justificaria estudos prioritários sobre política a adotar nessa matéria, com maiores reflexões sobre o tema, antes de querer adotar para a Nação um estatuto, como o da UNCITRAL, que pressupōe uma vigência de tratados mais univer- 
sais e generalizados sobre o tema, além do envelhecido Protocolo de Genebra de 1923, único diploma internacional vigente no Brasil.

Este é o meu Parecer, que tenho a honra de encaminhar ao ilustre Consultor Jurídico do Ministério das Relações Exteriores, Embaixador Prof. Dr. Miguel Franchini-Netto, igualmente Representante Permanente do Brasil junto à UNCITRAL, a respeito do PROJETO DE CONVENÇĀO SOBRE LEI-MODELO DE ARBITRAGEM COMERCIAL INTERNACIONAL, originário daquela Comissão das Nações Unidas.

São Paulo, Arcadas, em 09 de novembro de 1984.

Guido F.S. Soares

Professor Adjunto do Depto. de D. Internacional da Faculdade de Direito da Universidade de São Paulo 
ANEXO III (Tradução Livre do Autor)

Lei-Modelo sobre Arbitragem Comercial Internacional ${ }^{(12)}$

Adotada pela UNCITRAL na sua $18^{2}$ Sessão - (Viena, 12/VL/1985)

CAPÍTULO PRIMEIRO - DISPOSIÇŌES GERAIS

Art. 19

Campo de Aplicação ${ }^{(13)}$

1. A presente lei se aplica à arbitragem comercial(14) internacional; não atinge nenhum acordo multilateral ou bilateral em vigor neste Estado.

2. As disposições da presente lei, com exceção dos arts. 8ª, 9, 35 e 36 só se aplicam, se o lugar da arbitragem se situa no território deste Estado.

3. Uma arbitragem é internacional quando:

a) as partes numa convenção de arbitragem, no momento da conclusão da mencionada convenção, têm seus domicilios ${ }^{(15)}$ em Estados diferentes;

b) um dos lugares a seguir mencionados, se encontra situado fora do Estado no qual as partes têm seus domicílios:

i) o lugar da arbitragem, se estiver estipulado na convenção de arbitragem ou determinado em virtude da mesma;

(12) Tradução feita pelo autor a partir do texto em francês e inglês, publicado in Revue de Droit Uniforme, UNIDROIT, Roma, 1985/II, p. 320. (Nota do tradutor)

(13) Os títulos dos artigos destinam-se unicamente a facilitar a leitura do texto e não devem ser utilizados para fins de interpretação. (Nota do original)

(14) O termo "comercial" deverá ser interpretado num sentido amplo, a fím de designar. quaisquer questōes originadas de relações de caráter comercial, contratuais ou não contratuais. As relações de natureza comercial compreendem, sem estar limitadas, às seguintes transação: qualquer transação comercial relativa ao fornecimento ou à troca de mercadorias ou serviços; acordo de distribuição; representação comercial; "factoring"; "leasing"; construção de usinas; serviços de consultoria; engenharia; licenças; investimentos; financiamentos; "joint ventures" e outras formas de cooperação industrial ou comercial; transporte de mercadorias ou de passageiros por via áerea, marítima, ferroviária ou rodoviária. (Nota do original)

(15) "Their places of business"/"Leur établissements" A melhor tradução parecer ser "domicŕlio", no direito brasileiro. (Nota do tradutor) 
ii) qualquer lugar onde deva ser executada uma parte substancial das obrigaçōes originárias da relação comercial ou o lugar com o qual o objeto do litígio tenha a conexão mais relevante; (16)

c) as partes expressamente convencionaram que o objeto da convenção de arbitragem tenha relacionamento com vários países.

4. Para fins do $\S 3 \circ$ do presente artigo:

a) se uma parte tem mais de um domicílio, o domicilio a ser considerado, será aquele que tiver o mais estreito relacionamento com a convenção de arbitragem;

b) se uma parte não tiver domicílio, será considerada, como substituto, sua residência habitual.

5. A presente lei não afetará nenhuma outra lei do presente Estado, pela qual determinados litígios podem ser submetidos à arbitragem ou só o podem, pela aplicação de dispositivos de outras leis diversas da presente lei.

\section{Art. 2o}

\section{Definições e Regras de Interpretação}

Para os fins da presente lei:

a) o termo "arbitragem" designa qualquer arbitragem cuja organização esteja ou não confiada a uma instituição permanente de arbitragem;

b) a expressão "tribunal arbitral" designa um árbitro único ou um conjunto de árbitros;

c) termo "tribunal" designa um organismo ou um órgão do sistema judiciário de um Estado;

d) no caso de um dispositivo da presente lei, com exceção do art. 28 , deixar às partes a liberdade de decidir sobre uma determinada questão, esta liberdade inclui o direito de as partes autorizarem um terceiro, inclusive uma instituição, a decidir sobre a mesma questão;

(16) "Lieu avec lequel l'objet du différend a le lien le plus étroit"/"place with which the subject-matter of the dispute is most closely connected"; a tradução procurou ser fiel à doutrina brasileira. (Nota do tradutor) 
e) no caso de um dispositivo da presente lei se referir ao fato de as partes terem convencionado ou puderem convencionar sobre uma questão, ou se referir, de qualquer maneira, a uma convenção das partes, tal convenção englobará qualquer regulamentação de arbitragem que nela se mencione;

f) no caso de um dispositivo da presente lei, salvo os do parágrafo a) do art. 25 e da alínea 2 a) do art. 32, se referir a um pedido, este dispositivo se aplicará igualmente a um pedido reconvencional, e quando se referir a resposta, se aplicará, de igual forma, à réplica ao pedido reconvencional ${ }^{(17)}$.

Art. 30

\section{Recepção de comunicações escritas}

1. Salvo disposição em contrário das partes,

a) qualquer comunicação escrita é reputada como tendo sido recebida, quando for entregue, seja à pessoa do destinatário, seja no lugar de seu domicílio, ou na sua residência habitual ou no seu endereço postal; no caso de nenhum destes lugares puder ser encontrado, após uma busca razoável, uma comunicação escrita é reputada como tendo sido entregue, quando for enviada ao último domicílio, à última residência habitual ou ao último endereço postal conhecidos do destinatário, por carta registrada, ou por qualquer outro meio que ateste a tentativa de entrega;

b) a comunicação é repụtada como tendo sido recebida, no dia de sua entrega.

2. As disposições do presente artigo não se aplicam às cọmuncações havidas no quadro dos procedimentos judiciários ${ }^{(18)}$.

Art. 4은

Renúncia ao direito de apresentar objeções

Reputa-se como tendo renunciado ao direito de apresentar objeções a parte que, mesmo sabendo que um dos dispositivos da presente lei derrogável pelas partes, ou qualquer outra condição enunciada na convenção de arbitra-

(17) Traduziremos "demande"; "demande reconventionnelle"/"claim" "counter-claim" por pedido e pedido reconvencional. "Defense"; "conclusions en defense"/"defence"; "defence to such counter-claim" por: resposta e réplica ao pedido reconvencional. (Nota do tradutor)

(18) Embora o texto pudesse ter aproveitado a definição de "tribunal" ("tribunal"/"court") não o fez e empregou as expressões "dans le cadre de procédures judiciaires"/"in court proceedings". (Nota do tradutor) 
gem, não foram respeitados, ainda assim prossegue com a arbitragem, sem formular objeções num prazo devido ou fora do mesmo (se houver previsão de prazo para tal efeito).

Art. 5

\section{Casos de Intervenção do Tribunal}

Nas questões reguladas pela presente lei, o tribunal não poderá intervir, salvo nos casos por ela previstos.

Art. 6o

Tribunal ou Outra Autoridade Encarregada de Determinadas Funções de Assistência ou de Controle no Quadro da Arbitragem

As funções mencionadas nos arts. 11-3, 11-4, 13-3, 14, 16-3 e 34-2 serão confiadas a... (Cada Estado, ao adotar a lei-modelo precisará o tribunal ou os tribunais, ou, no caso de esta lei mencionar, qualquer outra autoridade competente para desempenhar as funções referidas).

\section{CAPÍTULO II - A CONVENÇÃO DE ARBITRAGEM}

Art. 70

\section{Definição e Forma da Convenção de Arbitragem}

1. Uma "convenção de arbitragem" é uma convenção pela qual as partes decidem submeter à arbitragem, quaisquer litígios ou determinados litígios que tenham surgido ou vierem a surgir entre elas, a respeito de uma relação de direito determinada, contratual ou a respeito de uma relação de direito determinada, contratual ou não contratual. Uma convenção de arbitagem poderá tomar a forma de uma cláusula compromissória em um contrato, ou de uma convenção separada.

2. A convenção de arbitragem deve ser por escrito. Uma convenção é por escrito no caso de ser consignada em um documento assinado pelas partes, numa troca de cartas, de comunicações de telex, de telegramas ou de qualquer outro meio de telecomunicação que ateste sua existência, ou ainda, na troca de reivindicações litigiosas no pedido e na sua resposta, na qual a existência daquela convenção seja alegada por uma parte e contestada por outra. A referência em um contrato a um documento contendo uma cláusula compromissória, equivale a uma convenção de arbitragem, na condição de que o citado contrato seja na forma escrita e que a referência seja de tal sorte, que faça da cláusula uma parte do contrato. 
Art. 8은

Convenção de Arbitragem e Ações Intentadas quanto ao Mérito ${ }^{(19)}$ perante um Tribunal

1. O tribunal perante o qual um litígio que verse sobre uma questão que faz parte de uma convençāo de arbitragem, remeterá as partes à arbitragem, se uma delas o pedir, desde o momento em que submete seus primeiros arrazoados quanto ao mérito do litígio, a menos que constate que a mencionada convenção seja nula, inoperante ou não susceptível de ser executada.

2. No caso de uma ação ser intentada perante um tribunal, conforme o $\S 1$ ㅇ do presente artigo, o procedimento arbitral poderá ser iniciado ou prosseguir, podendo uma sentença arbitral ser proferida, enquanto se aguarda a decisão do tribunal.

Art. 99

Convenção de Arbitragem e Medidas Cautelares perante um Tribunal

O pedido de uma das partes a um Tribunal, antes ou durante o procedimento arbitral, de medidas cautelares provisionais ou conservatórias dirigidas a um Tribunal, ou sua concessão por este, não são incompatíveis com uma convenção de arbitragem.

Art. 10

Número de árbitros

1. As partes são livres para convir sobre o número de árbitros.

2. Na falta de estipulação entre as partes, o número de árbitros será três.

Art. 11

Nomeação do Árbitro ou dos Árbitros

1. Ninguém poderá ser, em razão de sua nacionalidade, impedido de exercer as funçōes de árbitro, salvo estipulação em contrário das partes.

2. As partes são livres de estabelecer o procedimento de nomeação do árbitro ou dos árbitros, sem prejuízo das disposiçōes dos parágrafos $4^{\circ}$ e 5o do presente artigo.

(19) "Fond du différend"/"substance of the dispute": traduziremos por mérito do litígio. A idéia da Lei-Modelo é prestigiar o primeiro momento em que a parte comparece perante o Judiciário, e não a forma de apresentar sua exceção de extingüibilidde do processo judiciário. (Nota do tradutor) 
3. Na falta de convenção:

a) em caso de arbitragem por três árbitros, cada parte nomeará um árbitro e ambos os árbitros assim nomeados, escolherão o terceiro árbitro; no caso de uma das partes são nomear um árbitro, no prazo de 30 dias a contar da recepção de um pedido da outra parte para tal fim, ou se ambos os árbitros não se puserem de acordo sobre a escolha do terceiro árbitro, no prazo de 30 dias de sua nomeação deles, a nomeação será efetuada, a pedido de uma das partes, ao tribunal ou outra autoridade mencionada no art. 6?.

b) em caso de arbitragem por um árbitro único, se as partes não puderem acordar sobre a escolha do árbitro, este será nomeado a pedido de uma das partes, pelo tribunal ou autoridade mencionada no art. 6‥

4. Se, durante um procedimento de nomeação convencionado pelas partes,

a) uma parte não se comportar de acordo com o citado procedimento;

b) as partes ou os dois árbitros, não conseguirem chegar a um acordo de conformidade com o citado procedimento;

c) um terceiro, inclusive uma instituição, não cumprir com sua missão que lhe foi confiada no citado procedimento; qualquer das partes poderá solicitar ao tribunal ou à autoridade mencionada no art. 6º, conforme os $\$ \S 3^{\circ}$ e $4^{\circ}$ do presente artigo, tomar as providências desejadas, a menos que a convenção relativa à nomeação, não estipule outros meios para assegurar a citada nomeação.

5. A decisão sobre matéria dos parágrafos $3^{\circ}$ e $4^{\circ}$ do presente artigo, confiadas a um tribunal ou autoridade mencionada no art. 6, não é susceptível de recurso. O tribunal ou outra autoridade, ao nomear um árbitro, deverá levar em consideração quaisquer qualificações exigidas pelas partes na convenção e quaisquer considerações apropriadas para garantir a nomeação de um árbitro independente e imparcial, e, no caso de nomeação de um árbitro único ou de um terceiro árbitro, deverá igualmente considerar o fato de ser preferível nomear um árbitro de nacionalidade diferente daquela das partes.

Art. 12

Motivos de Recusa (Grounds for Challenge/Motifs de Recusation)

1. No caso de uma pessoa ser consultada sobre sua possível nomeação como árbitro, deverá assinalar quaisquer circunstâncias de natureza a levantar dúvidas legítimas sobre sua imparcialidade ou independência. A partir da data de sua nomeação e durante todo procedimento arbitral, o árbitro deverá assinalar, sem tardança, aquelas circunstâncias às partes, a menos que já o tenha feito. 
2. Um árbitro não poderá ser recusado, senão no caso de existirem circunstâncias de natureza a levantar dúvidas legítimas sobre sua imparcialidade ou independência, ou no caso de não possuir ele as qualificações convencionais pelas partes. Uma parte não poderá recusar o árbitro que nomeou ou em cuja nomeação participou, senão por uma causa de que teve conhecimento após aquela nomeação.

Art. 13

Procedimento de Recusa (Challenge Procedure)

1. Sob reserva do disposto no $\S 3$ o do presente artigo, as partes são livres para estabelecer o procedimento de recusa do árbitro.

2. Na falta de acordo entre as partes, aquela que tenha a intenção de recusar um árbitro, deverá expor, por escrito, as razões da recusa do tribunal arbitral, no prazo de quinze dias, a contar da data da qual teve conhecimento da constituição do tribunal, ou da data da qual teve conhecimento das circunstâncias mencionadas no art. 12-2. No caso de o árbitro recusado não se retirar, ou no de a outra parte não aceitar a recusa, o tribunal arbitral se pronunciará sobre a recusa.

3. Se a recusa não puder ser obtida pelos procedimentos convencionados pelas partes ou pela aplicação do $\S 2$ o do presente artigo, a parte que recusa poderá, no prazo de trinta dias após ter recebido a comunicação da decisão rejeitando a recusa, solicitar ao tribunal ou a outra autoridade mencionada no art. 69, tomar uma decisão, que será sem recurso, sobre a recusa; no aguardo de tal decisão, o tribunal arbitral, inclusive o árbitro recusado, poderão prosseguir com a arbitragem e prolatar uma sentença.

Art. 14

Impedimento ${ }^{(20)}$ ou Incapacidade de um Árbitro

1. No caso de um árbitro se encontrar de fato ou de direito na impossibilidade de realizar sua missão, ou, por qualquer outra razâo, não se despedir de suas funçōes num prazo razoável, seu mandato terminará, se o árbitro não se despedir ou se as partes convencionarem de por-lhe fim. No caso de subsistir um desacordo quanto a quaisquer de tais motivos, quaisquer das partes podem pedir ao tribunal ou à autoridade mencionada no art. 60, tomar uma decisão, que não será susceptível de recurso, sobre a cessação do mandato.

(20) Parece que a melhor tradução para "carence d'un arbitre"/"failure to act", seja impedimento no direito brasileiro, em que pese o sentido técnico da expressão em Processo Civil. (Nota do tradutor) 
2. O fato de, na aplicação do presente artigo ou do art. 13-2, um árbitro despedir-se ou uma parte aceitar que o mandato do árbitro tenha fim, não implicará no reconhecimento dos motivos mencionados no art. 12-2 ou no presente artigo.

Art. 15

Nomeação de um Árbitro Substituto

Por ocasiảo do término de um mandato de um árbitro, segundo os arts. 13 ou 14, ou de sua partida por qualquer outra razão, ou se seu mandato for revogado de acordo com as partes, ou em qualquer outro caso, onde se ponha fim a seu mandato, um árbitro substituto será nomeado de conformidade com as regras aplicáveis à nomeação de um árbitro a ser substituído.

\section{CAPÍTULO IV - COMPETÊNCIA DO TRIBUNAL ARBITRAL} Art. 16

Competência do Tribunal Arbitral para Decidir sobre sua Própria Competência

1. O tribunal arbitral poderá decidir sobre sua própria competência, inclusive sobre qualquer exceção relativa à existência ou à validade da convenção de arbitragem. Para tais fins, a cláusula compromissória que faça parte de um contrato, é considerada como uma convenção separada das outras cláusulas do contrato. A constatação da nulidade do contrato pelo tribunal arbitral, não causará, de pleno direito (ipso jure), a nulidade da cláusula compromissória.

2. A exceção de incompetência do tribunal arbitral deverá ser apresentada, não mais tardar, até o depósito da réplica ao pedido reconvencional ${ }^{(21)}$. $\mathrm{O}$ fato de uma parte ter designado um árbitro ou participado na sua designação, não a priva do direito de opor tal exceção. A exceção oposta de que a questão litigiosa excederia os poderes do tribunal arbitral, deverá ser apresentada, tão logo a questão alegada como excedente a seus poderes, for levantada perante o procedimento arbitral. Em ambos os casos, o tribunal arbitral poderá admitir uma exceção levantada após os prazos previstos, se julgar que o retardamento é devido a uma causa válida.

3. O tribunal poderá decidir sobre a exceção contemplada no $\S 20$ do presente artigo, seja tratando-a como uma questão preliminar, seja na sentença sobre o mérito. Se o tribunal arbitral determinar que, a título de questão preliminar, é competente, qualquer das partes poderá, nos trinta dias após a comunica-

(21) "Au plus tard lors du dépôt des conclusions en défence"/"not later than the submission of the statement of defence"; preferimos o texto em francês, na tradução. Vide nota (17) "hic". (Nota do tradutor) 
ção desta decisão, solicitar ao tribunal estabelecido no art. 6, decidir sobre tal ponto, decisão que não será susceptível de recurso; enquanto pendente o julgamento sobre tal pedido, o tribunal arbitral será livre para prosseguir com o procedimento arbitral e prolatar uma sentença.

Art. 17

\section{Poder do Tribunal Arbitral de Ordenar Medidas Provisórias}

Salvo convenção contrária das partes, o tribunal arbitral poderá, a pedido de uma das partes, ordenar às partes tomar qualquer medida provisória ou conservatória que julgue necessária, no que diz respeito ao objeto do litígio. $O$ tribunal arbitral poderá, para tal, exigir de qualquer parte providenciar as garantias adequadas ${ }^{(22)}$.

\section{CAPÍTULO V - CONDUÇÃO DO PROCEDIMENTO ARBITRAL} Art. 18

\section{Igualdade de Tratamento das Partes}

As partes deverão ser tratadas em pé de igualdade e cada parte deverá ter todas as possibilidades de fazer valer seus direitos.

Art. 19

\section{Determinação das Regras de Procedimento}

1. Salvo disposição em contrário da presente lei, as partes são livres para convencionar o procedimento a ser seguido pelo tribunal arbitral.

2. Na falta de convenção neste sentido, o tribunal arbitral poderá, com as reservas das disposiçōes da presente lei, proceder na arbitragem como considerar apropriado. Os poderes conferidos ao tribunal arbitral compendem aquele de julgar a admissibilidade, a relevância e a pertinência de qualquer prova produzida.

Art. 20

\section{Lugar da Arbitragem}

1. As partes são livres para decidir sobre o lugar da arbitragem. $\mathrm{Na}$ falta de tal decisão, o lugar será determinado pelo tribunal arbitral, levando-se em consideração as circunstâncias do caso, inclusive a conveniência das partes.

(22) "exiger de toute partie le versement d'une provision appropriée"/"to provide appropriate security in connection with such measure"; garantias parece ser a tradução adequada, para dar a idéia de generalidade. (Nota do tradutor) 
2. Não obstante o disposto no $\S 1 \%$ do presente artigo, o tribunal arbitral poderá, salvo convenção em contrário das partes, reunir-se em qualquer lugar que julgar apropriado, para consultas entre seus membros, audiência de testemunhas, e peritos ou das partes, ou para inspeçōes de mercadorias, outros bens ou documentos.

Art. 21

Instalação do Procedimento Arbitral

Salvo a disposição em contrário das partes, o procedimento arbitral relativo a um litígio determinado, terá início na data em que o pedido de submissão deste litígio a arbitragem, for recebido pelo requerido ${ }^{(23)}$.

Art. 22

Língua

1. As partes serão livres para convencionar a língua ou as línguas a ser utilizadas no procedimento arbitral. Na falta de acordo em tal sentido, o tribunal arbitral decidirá sobre a língua ou as línguas a ser utilizadas no procedimento. $\mathrm{O}$ acordo ou a decisão, a menos que especificado de outra forma, aplicar-se-ão a qualquer declaração escrita de uma das partes, a qualquer procedimento oral e a qualquer sentença, decisão ou outra comunicação do tribunal.

2. O tribunal arbitral poderá ordenar que qualquer documento seja acompanhado de uma tradução na língua ou nas línguas convencionadas pelas partes ou escolhidas pelo tribunal arbitral.

Art. 23

Declaraçōes no Pedido e na Resposta

1. No prazo convencionado pelas partes ou fixado pelo tribunal arbitral, o requerente $^{(24)}$ deverá enunciar os fatos em apoio a seu pedido ${ }^{(25)}$, os pontos li-

(23) Defendeur/respondent: traduzimos por requerido. Vide nota (24) a seguir. (Nota do tradutor)

(24) Demandeur/claimant serão traduzidos por requerente. Vide nota (23) anterior. (Nota do tradutor)

(25) Demande/claim serão traduzidos por pedido. (Nota do tradutor) 
tigiosos e o objeto do pedido ${ }^{(26)}$ e o requerido deverá enunciar sua resposta ${ }^{(27)}$ a propósito daquelas questōes, a menos que as partes tenham convencionado que tais indicaçōes devam estar constantes nas conclusões. As partes poderão fazer suas conclusōes acompanhadas de quaisquer documentos que julgarem pertinentes, ou nelas mencionar os documentos ou outros meios de provas, que produzirāo.

2. Salvo convencionado em contrário pelas partes, qualquer das partes poderá modificar ou completar seu pedido ou sua resposta, no curso do procedimento arbitral, a menos que o tribunal arbitral considere não dever autorizar tais emendas, em razão do retardamento com que são formuladas.

Art. 24

\section{Procedimento Oral e Procedimento Escrito}

1. Salvo convenção contrárias das partes, o tribunal arbitral decidirá se o procedimento deverá comportar fases orais para a produção de provas, ou para a exposição oral de argumentos, ou se ele se desenvolverá na base de documentos ou outros materiais. No entanto, a menos que as partes não tenham convencionado que não haverá procedimento oral, o tribunal arbitral organizará este procedimento, no estágio apropriado do procedimento arbitral, se uma das partes lhe fizer um pedido para tal.

2. As partes deverão ser notificadas com tempo suficientemente anterior a qualquer audiência ou sessão do tribunal arbitral, para fins de inspeção de mercadorias, outros bens ou documentos.

3. Quaisquer declaraçōes, documentos ou informaçōes que uma das partes produzir ao tribunal arbitral, deverão ser comunicados à outra parte. Qualquer relatório de peritos ou documentos apresentados como prova e nos quais o tribunal arbitral poderá apoiar-se para decidir, deverão, igualmente, ser comunicados às partes.

Art. 25

Revelia ou Não Comparecimento de uma Parte (Defaut d'une Partie/Default of a Party)

(26) L'Objet de la demande/the relief or remedy sought serão traduzidos por objeto do pedido. (Nota do tradutor)

(27) Défenses/defence serão traduzidos por resposta. (Nota do tradutor) 
Salvo convenção contrária das partes, no caso de, sem apresentar um impedimento legítimo:

a) o requerente não apresentar seu pedido conforme o artigo 23-1, o tribunal arbitral encerrará o procedimento arbitral;

b) o requerido não apresentar sua resposta conforme o artigo 23-1, o tribunal arbitral prosseguirá com o procedimento, sem considerar tal revelia como, ela mesma, uma admissão das alegaçōes do requerente;

c) uma das partes se omitir em comparecer a uma audiência ou em produzir documentos, o tribunal poderá continuar com o procedimento e prolatar a sentença arbitral, na base dos elementos de prova de que disponha.

Art. 26

Perito Nomeado pelo Tribunal Arbitral

1. Salvo convenção em contrário das partes, o tribunal arbitral:

a) poderá nomear um ou vários peritos encarregados de apresentar-lhe relatórios, sobre pontos precisos que determinar;

b) poderá solicitar a uma das partes fornecer ao perito quaisquer informaçōes apropriadas ou submeter-lhe ou tornar-lhe acessível, para fins de exame, quaisquer documentos, mercadorias ou bens.

2. Salvo convenção contrária das partes,se uma das partes solicitá-lo, ou se o tribunal arbitral julgar necessário, o perito, após a apresentação de seu relatório escrito ou oral, participará em uma audiência na qual as partes poderão interrogá-lo e fazer vir, na qualidade de testemunhas, peritos que deporão sobre as questōes litigiosas.

\section{Art. 27}

\section{Assistência dos Tribunais para a Obenção de Provas}

O tribunal arbitral, ou uma das partes, com a aprovação do tribunal arbitral, pderá solicitar a um tribunal [judiciário] competente deste Estado, a assistência para a obtenção de provas. O tribunal poderá satisfazer a tal pedido, nos limites de sua competência e conforme as regras relativas à obtenção de provas. 


\section{CAPÍTULO VI - PROLAÇĀO DA SENTENÇA ARBITRAL E ENCER- RAMENTO DO PROCEDIMENTO}

Art. 28

Regras aplicáveis ao Mérito(28) do Litígio

1. O tribunal arbitral decidirá o litígio conforme as regras de direito escolhidas pelas partes, como aquelas aplicáveis ao mérito do litígio. Qualquer indicação de um direito ou de um sistema jurídico de um Estado determinado, deverá ser interpretada, salvo estipulação expressa em sentido contrário, como designando diretamente as regras jurídicas de direito material deste Estado e não suas regras de conflitos de leis(29).

2. Na falta de qualquer indicação pelas partes naquele sentido, o tribunal arbitral aplicara a lei designada pela regra de conflito de leis que ele julgar aplicável na espécie ${ }^{(30)}$.

(28) "Fond du differend"/"substance of dispute"; a melhor tradução parece ser mérito do litígio, também quanto à determinação da lei de regência do negócio em litígio, perante o(s) árbitro(s). (Nota do tradutor). Vide nota 19 "hic".

(29) Parece que os $\S \S 1^{\circ}$ e $2^{\circ}$ do art. 28 devem ser lidos da seguinte maneira: a) no caso de eleição pelas partes de um Direito de um Estado para regular o mérito do litígio, a norma eleita é de direito material e não conflitual (salvo indicação contrária expressa das partes); b) na lacuna de eleição de direito aplicável, realizada pelas partes, cabe aos árbitros a determinação do direito material que irá reger as relações litigiosas, o que eles farão, previamente, consultando as normas do Direito Internacional Privado que julgarem adequado à questão (igualmente, se estiverem autorizados pelas partes a buscarem o direito material aplicável). Em outras palavras: a) no caso de eleição de norma aplicável, diretamente eleita pelas partes, não se admite "qualquer remissão por ela feita a outra lei" (proibição da remissão ou reenvio, que corresponde aos termos do art. 16 da Lei de Introdução ao Código Civil Brasileiro); b) na lacuna de uma "professio juris" das partes, cabe aos árbitros descobrir a lei material aplicável, através de uma investigação intelectual, a começar por inquirir qual a regra de conflito adequada ao litígio, a qual, por sua vez, indicará o direito material estatal aplicável (e, neste segundo momento, aquela proibição de reenvio ou remissão a outros sistemas, será operante, ex vi do $\S 10$ do art. 28). (Nota do tradutor)

(30) Vide nota anterior. (Nota do tradutor) 
3. O tribunal arbitral decidira "ex bono et aequo" ou na qualidade de "amiable compositeur"(31), somente no caso de as partes terem-no expressamente autorizado a tal.

4. Em quaisquer casos, o tribunal arbitral decidirá conforme as estipulações do contrato e deverá tevar em consideração os usos do comércio aplicáveis à transação.

Art. 29

Tomada de Decisāo por Vários Árbitros

No procedimento arbitral que comportar mais de um árbitro, qualquer decisão do tribunal arbitral será, salvo convenção contrária das partes, tomada pela maioria de seus membros. Contudo, as questões de procedimento poderão ser resolvidas pelo árbitro-presidente, se este estiver autorizado pelas partes, ou por todos os membros do tribunal arbitral.

(31) Interessante transcrever o texto em inglês do dispositivo:

"The arbitral tribunal shall decide ex aequo et bono or as amiable compositeur only if the parties have expressly authorized it to do so". (Itálicos no original).

Veja-se a nota (8) no presente trabalho, relativa à tradução do Regulamento da UNCITRAL, onde há dispositivo comparável ao presente. No texto oficial em francês, do Regulamento da UNCITRAL, no art. $33 \S 2^{\circ}$, escreve-se: "Le tribunal arbitral ne statue en qualite 'd'amiable compositeur' (ex bono et aequo) que si le tribunal arbitral y a été expressément autorisé par les parties et si ce type d'arbitrage est permis par la loi applicable à la procédure arbitrale" (com aspas e itálicos no original). Na verdade, o texto mais correto de redação é o da Lei-Modelo da UNCITRAL, levandoë em consideração que tanto o árbitro, digamos, normal (que a doutrina francesa denomina "arbitre en droit") quanto o "amiable compositeur" (que traduzimos, talvez impropriamente, por julgador por eqüidade, na nota 8 "hic") podem, seja aplicar a norma de direito (do contrato, do Estado ou os usos do comércio aplicáveis à transação) de maneira automática, seja aplicá-las de maneira a atender sua finalidade de realizar a justiça, isto é, com eqüidade. Isto posto, a conjunção disjuntiva em inglês or e sua correspondente em português ou, na redação do $§ 3^{\circ}$ do art. 28 da LeiModelo indicam, com acerto, a existência de duas alternativas, que não se confundem: árbitro ou "amiable compositeur"/ aplicação do direito estrito ou aplicação do direito temperado com a eqüidade. (nota do tradutor) 
Art. 30

Resolução do Litígio ${ }^{(32)}$ por Acordo das Partes ${ }^{(33)}$

1. Se durante o procedimento arbitral, as partes se entenderem para resolver o litígio, o tribunal arbitral terminará o procedimento arbitral e, se as partes the fizerem um pedido, e ele não encontrar objeções, constatará o fato por uma sentença arbitral prolatada nos termos convencionados pelas partes.

2. A sentença prolatada nos termos convencionados pelas partes será proferida segundo o disposto no art. 31 e deverá mencionar que se trata de uma sentença. Tal sentença terá o mesmo "status" e o mesmo efeito que qualquer outra sentença pronunciada sobre o mérito do litígio.

Art. 31

Forma e Conteúdo da Sentença

1. A sentença será proferida por escrito e será assinada pelo árbitro ou pelos árbitros. No procedimento arbitral com mais de um árbitro, as assinaturas da maioria dos membros do tribunal arbitral serão suficientes, desde que seja mencionada a razão da omissão das outras.

2. A sentença deverá ser motivada, salvo se as partes tiverem convencionado que tal não deva ser, ou que se trata de uma sentença prolatada nos termos convencionados pelas partes, conforme 0 art. 30 .

3. A sentença deverá mencionar a data na qual foi proferida, assim como o lu ar da arbitragem, determinado conforme o art. 20-1. A sentença é reputada como tendo sido proferida no citado lugar.

4. Após a prolação da sentença, uma cópia assinada pelo árbitro ou pelos árbitros, conforme o $\S 1^{\circ}$ do presente artigo, deverá ser entregue a cada uma das partes.

(32) "Règlement par Accord des Parties"/"Settlement": o termo regulamentação, em português, seria inadequado, devido à conotação de ser indicativo de "resolução", igualmente de "normativização". No caso, trata-se do substantivo abstrato derivado do verbo resolver na sua acepção mais corrente, sem conotações de conformidade com qualquer regra antericr. (Nota do tradutor)

(33) O texto em francês refere-se a "par accord des parties" e não a "sentence arbitrale rendue d'accord partie" do Regulamento. Veja-se nota (9) "hic". (Nota do tradutor) 
Art. 32

\section{Encerramento do Procedimento}

1. O procedimento arbitral será encerrado com o pronunciamento da sentença definitiva ou por uma ordem de encerramento proferida pelo tribunal arbitral, nos termos do $§ 2^{\circ}$ deste artigo.

2. O tribunal arbitral ordenará o encerramento do procedimento arbitral quando:

a) o requerente retirar seu pedido, a menos que o requerido a isto faça objeção e que o tribunal arbitral reconheça que este tenha legítimo interesse a que o litígio seja resolvido de maneira definitiva;

b) as partes convencionem encerrar o procedimento;

c) o tribunal arbitral constate que o prosseguimento do processo arbitral se tenha, por qualquer razão, tornado desnecessário ou impossível.

3. O mandato do tribunal arbitral cessará com o encerramento do procedimento arbitral, sob reserva das disposições do art. 33 e do parágrado 4을 do art. 34.

Art. 33

Retificação e Interpretação da Sentença; Sentença Adicional

1. Nos trinta dias que se seguirem à recepção da sentença, a menos que as partes tenham convencionado outro prazo,

a) qualquer das partes poderá, mediante notificação á outra, pedir ao tribunal arbitral retificar, no texto da sentença, qualquer erro de cálculo, erro material ou tipográfico, ou erro da mesma natureza;

b) se as partes convencionaram a propósito, uma parte poderá, mediante notificação à outra, pedir ao tribunal arbitral dar uma interpretação sobre um ponto ou passagem precisos da sentença.

Se o tribunal arbitral considerar que o pedido é justificado, fará a retificação ou dará a interpretação nos trinta dias que se seguirem à recepção do pedido. A interpretação fará parte integrante da sentença.

2. O. tribunal arbitral poderá, por sua iniciativa própria, retificar qualquer erro do tipo mencionado na alínea a) do parágrafo 1 - do presente artigo, nos trinta dias que se seguirem à data da sentença. 
3. Salvo convenção contrária das partes, qualquer das partes, poderá, mediante notificação à outra, pedir ao tribunal arbitral nos trinta dias que se seguirem à recepção da sentença, prolatar uma sentença adicional sobre os pontos levantados ano curso do procedimento arbitral, mas omitidos na sentença. Se julgar o pedido justificado, o tribunal poderá completar sua sentença em sessenta dias.

4. O tribunal arbitral poderá prolongar, se for necessário, o prazo que dispōe para retificar, interpretar ou completar a sentença, em virtude dos $\S 1$ ou $\S 3$ o do presente artigo.

5. As disposiçōes do art. 31 aplicar-se-ão á retificação ou à interpretação da sentença ou à sentença adicional.

\section{CAPÍTULO VII - RECURSOS CONTRA A SENTENÇA}

\section{Art. 34}

\section{Pedido de Anulação como Recurso Exclusivo contra a Sentença Arbitral}

1. Os recursos apresentados perante um tribunal judiciário contra uma sentença arbitral, somente poderão versar sobre um pedido de anulação, conforme . os $\S 2^{\circ}$ e $\S 3^{\circ}$ do presente artigo.

2. Só será passível de anulação pelo tribunal previsto no art. 6, as sentenças arbitrais, nas condições seguintes:

a) a parte que apresenta o recurso, faça a prova:

i) de que a parte na convenção de arbitragem mencionada no art. $7^{\circ}$, era incapaz; ou que a mencionada convenção não era válida segundo a lei à qual as partes a subordinaram, ou, na falta de indicação para tal efeito, em virtude da lei deste Estado; ou

ii) que a parte recorrente não foi devidamente informada na nomeação de um árbitro ou do procedimento arbitral, ou que lhe foi impossível por qualquer outra razão, de fazer valer seus direitos ${ }^{(34)}$; ou

(34) "Impossible de... faire valoir ses droits" "unable to present his case"; ambos os textos são imprecisos quanto às razões de anulabilidade da sentença arbitral, pelo que deixamos o texto em português com a mesma imprecisão. Compare-se com o disposto no art. 18 "hic". (Nota do tradutor) 
iii) que a sentença se refira a um litígio não contemplado no compromisso ou não compreendido nas previsões da cláusula compromissória, ou que contenha decisōes que ultrapassam os termos do compromisso ou da cláusula compromissória, estando estendido, contudo, que, se as disposições da sentença na matéria submetida à arbitragem podem ser dissociadas daquelas não submetidas à arbitragem, somente a parte da sentença que contenha decisões sobre questões não submetidas à arbitragem pderão ser anuladas; ou

iv) que a constituição do tribunal arbitral ou o procedimento arbitral não foram conformes à convenção das partes, na condição de que tal convenção não seja contrária a um dispositivo da presente lei inderrogável pelas partes ou, na falta daquela convenção, que ela não esteja conforme a presente lei; ou

b) o tribunal [judiciário] constate:(35)

i) que o objeto do litígio não é susceptível de ser resolvido por arbitragem, conforme a lei do presente Estado; ou

ii) que a sentença arbitral é contrária à ordem pública do presente Estado.

3. Um pedido de anulação não poderá ser apresentado senão após a expiração do prazo de três meses, a contar da data em que a parte que apresenta o pedido recebeu comunicação da sentença [arbitral], ou se um pedido tiver sido feito em virtude do art. 33, a contar da data na qual o tribunal arbitral tomou uma decisāo sobre este pedido.

4. O tribunal [judiciário], no caso de ter sido solicitado por uma das partes a anular a sentença arbitral, se for conveniente, poderá determinar a suspensão do processo [judicial] de anulação, pelo período que designar, a fim de dar ao tribunal arbitral a possibilidade de reiniciar o procedimento arbitral ou de tomar qualquer outra providência no sentido de, a juízo do tribunal arbitral, eliminar os motivos da anulação alegados.

\section{CAPÍTULO VIII - RECONHECIMENTO E EXECUÇÃO DAS SENTENÇAS ARBITRAIS}

Art. 35

Reconhecimento e Execução

1. A sentença arbitral, qualquer que seja o país onde tenha sido proferida, será reconhecida como tendo força obrigatória e, a pedido por escrito ao tribu-

(35) Os termos entre colchetes foram acrescentados pelo tradutor, para fins de maior clareza. (Nota do tradutor) 
nal competente, será executada, com as reservas das disposições do presente artigo e do art. 36 .

2. A parte que invocar a sentença ou que pedir sua execução, deverá providenciar o original devidamente autenticado ou uma cópia devidamente certificada da mesma, assim como o original da convenção de arbitragem, mencionada no art. $7^{\circ}$ ou uma cópia devidamente certificada. Se a mencionada sentença ou a mencionada convenção de arbitragem não estiverem redigidas na língua oficial deste Estado, a parte produzirá sua tradução devidamente legalizada nesta língua ${ }^{(36)}$.

Art. 36

\section{Motivos de Recusa de Reconhecimento ou de Execução ${ }^{(37)}$}

1. O reconhecimento ou a execução de uma sentença arbitral, qualquer que seja o país onde tiver sido proferida, não poderão ser recusados, senão nas seguintes condições:

a) a pedido da parte contra a qual é invocada, se a citada parte fizer, ao tribunal [judiciário] competente, ao qual é encaminhado o reconhecimento ou a execução, prova de:

i) que a parte na convenção de arbitragem mencionada no art. $7^{\circ}$, era incapaz; ou que a mencionada convenção não era válida segundo a lei à qual as partes a submeteram, ou, na falta de indicação para tal efeito, em virtude da lei do país onde a sentença arbitral foi prolatada;

ii) que a parte contra a qual a sentença [arbitral] é invocada, não foi devidamente informada sobre a designação de um árbitro ou do procedimento arbitral, ou que não lhe foi possível, por qualquer outra razão, fazer valer seus direitos $^{(38)}$; ou

(36) As condições mencionadas neste parágrafo visam a estabelecer as normas mais restritivas. Não seria, pois, contrário à harmonização pretendida pela Lei-Modelo, que um Estado estabeleça condições menos rigorosas. (Nota do texto original)

(37) Os termos entre colchetes foram colocados pelo tradutor, para maior clareza do texto, segundo o Direito brasileiro. (Nota do tradutor)

(38) Vide nota (34) "hic", sobre este conceito. (Nota do tradutor) 
iii) que a sentença [arbitral] se refere a um litígio não previsto no compromisso ou não relativo ás previsões da cláusula compromissória, ou que contenha decisões que ultrapassem os termos do compromisso ou da cláusula compromissória, devendo-se, contudo, entender que, se as disposiçōes da sentença [arbitral] que se referem a questões submetidas à arbitragem, puderem ser dissociadas daqueles que se refiram a questōes não submetidas à arbitragem, somente a parte da sentença [arbitral] que contenha decisões sobre questōes submetidas à arbitragem, poderão ser reconhecidas ou executadas; ou

iv) que a constituição do tribunal arbitral, ou do procedimento arbitral, não estão conformes à convenção das partes ou, na falta de tal convenção, à lei do país onde a arbitragem teve lugar; ou

v) que a sentença [arbitral] não se tenha ainda tornado obrigatória para as partes, oư tenha sido anulada ou suspensa por um tribunal [judiciário] do páis no qual ou sob cuja lei tenha sido a mesma [sentença arbitral] prolatada; ou

b) se o tribunal [judiciário] constatar que:

i) o objeto do litígio não é susceptível de ser resolvido por arbitragem, conforme a lei do presente Estado; ou que

ii) o reconhecimento ou a execução da sentença [arbitral] contrariam a ordem pública do presente Estado.

2. Se um pedido de anulação ou de suspensão de uma sentença [arbitral] for apresentado a um tribunal [judiciário] considerado na sub-alínea 1 a) v) do presente artigo, o tribunal [judiciário] ao qual são solicitados o reconhecimento ou a execução, poderá, se julgar apropriado, suspender sua decisão e pode, igualmente, a pedido da parte que solicita o reconhecimento ou a execução da sentença [arbitral], ordenar à outra parte, apresentar as garantias apropriadas. 